\title{
Groundwater in catchments headed by temperate glaciers: A review
}

\author{
Aude Vincent $^{\mathrm{a}, *}$, Sophie Violette ${ }^{\mathrm{b}}$, Guðfinna Aðalgeirsdóttir ${ }^{\mathrm{c}}$ \\ ${ }^{a}$ Geo-resources and Environment Laboratoy, ENSEGID - INP Bordeaux, 1 allée Fernand Daguin, 33600 Pessac, France \\ ${ }^{\mathrm{b}}$ Geology Laboratory, École Normale Supérieure, 24 rue Lhomond, 75005, Paris, France \\ ${ }^{\mathrm{c}}$ Glaciology Team, Faculty of Earth Sciences, University of Iceland, Reykjavik, Iceland
}

\section{A R T I C L E I N F O}

\section{Keywords:}

Groundwater

Glacier

Hydrogeology

Recharge

Climate change

Water resource

Water hazard

\begin{abstract}
A B S T R A C T
Catchments headed by temperate glaciers are severely impacted by climate change, and extensively studied from glaciological and surface hydrology perspectives. However groundwater in the same catchments is much more seldom mentioned, and even less studied.

The few available studies found in the scientific literature tend to show a particularly high recharge of aquifers by glacial meltwater, a strong connection between surface and ground waters, and quite high hydraulic permeability in moraines and tills aquifers. New and more systematic studies could confirm and details these results. Such characteristics suggest that groundwater in coastal catchments headed by temperate glaciers could feed offshore fresh groundwater stocks. The role of potential deeper aquifers in fractured bedrock remains completely unknown.

The numerous examples of natural hazards and of the sensitivity of water resources to the water cycle in catchments headed by temperate glaciers underline the importance of the study of hydrogeology, and of socioeconomic aspects, in these catchments where population is glacier-dependant.

The study of groundwater in catchments headed by temperate glaciers is just at the start and there is much to be studied.
\end{abstract}

\section{Introduction}

The research addressing glaciers response to climate change is well developed and is now looking not only at changes in mass balance, but also at the associated effects on subglacial hydrology (see definition in Table 1) and downstream hydrology. However, impact on the groundwater component is rarely considered, even though assessment of evolving groundwater dynamic (recharge, discharge and storage) will be required to forecast the evolution of water resources and of water related hazards under climate change. A few papers (see Section 1.2) do bring first insights into the role of groundwater in glacierised catchments (see definition in Table 1), but its systematic study is yet to be done.

This review will focus on temperate glaciers (see definition in Table 1), and eventually polythermal glaciers (see definition in Table 1). Their bases, at melting point, are from different factors including geothermal heat (as the ice layer has an isolation effect), pressure melting (due to ice thickness), and frictional heat. They thus present liquid water at their interface with the ground.

The present review is first of all presenting studies of glacierised catchments overlooking hydrogeology (see definition in Table 1)
(Section 1.1, 45 studies cited in this review, only a fraction of the ones existing), and examples of identified or figured out aquifers (see definition in Table 1) in catchments headed by temperate glaciers (Section 1.2, see Tables 2 and 3, respectively 49 and 26 studies). Then the role such aquifers play in the water cycle, i.e. their fundamental dynamic from recharge to their outlets, is explored (Section 2, see Tables 2 and 3):

- What part does subglacial hydrology play in the recharge of aquifers within glacierised watersheds? (Section 2.1).

- How intense are the surface-underground water exchanges in catchments headed by temperate glaciers? (Section 2.2).

- What are the hydraulic characteristics of those aquifers? (Section 2.3).

- What particular (micro)biodiversity is associated with hydrosystems influenced by glacial meltwater, and how is it responding to climate change? (Section 2.4).

- Emerging research lines are then set out, which will allow to consider the future evolution of catchments headed by temperate glaciers (Sections 3, 4 and 5):

- What are the effects of glacial meltwater runoff on offshore

\footnotetext{
* Corresponding author.

E-mail address: avincent@phare.normalesup.org (A. Vincent).
} 
Table 1

Definitions of main terms.

\begin{tabular}{|c|c|}
\hline Aquifer & $\begin{array}{l}\text { Permeable geological layer, where pores or fractures are at least partly or fully saturated with water, which allows the extraction of an } \\
\text { appreciable volume of water }\end{array}$ \\
\hline Englacial hydrological system & Hydrological system inside a glacier, formed by the interconnection of crevasses, moulins, and voids \\
\hline Esker & $\begin{array}{l}\text { Long ridge, up to several } \mathrm{km} \text { long and several meters high, linear or sinuous, shaped by heterogeneous sediments including gravel carried and left } \\
\text { by subglacial water streams (Boulton et al., 2007; Fridlund, 2017) }\end{array}$ \\
\hline Glacierised catchment & Catchment which is partly covered by ice \\
\hline Groundwater stock & Water stored beneath the ground surface, in the pores or fractures of an aquifer \\
\hline Hydraulic conductivity & Physical characteristic of an aquifer, determining the capacity of water to flow inside the aquifer under the effect of an hydraulic gradient \\
\hline Hydrogeology & Groundwater flux and stock, and study of their dynamic \\
\hline Jökulhlaup & $\begin{array}{l}\text { Include the outburst floods of ice-dammed lakes, as well as the floods provoked by geothermal fields forming subglacial lakes draining } \\
\text { periodically, and by the immediate draining of the meltwater formed during the volcanic eruptions (Björnsson and Pálsson, 2008) }\end{array}$ \\
\hline Karstic hydrosystem & $\begin{array}{l}\text { Aquifer system developed in carbonate formation under mechanical and geochemical interaction with recharge fluxes highly charged in } \\
\text { atmospheric } \mathrm{CO}_{2}\end{array}$ \\
\hline Moraine & $\begin{array}{l}\text { Accumulation of rocks debris of various size carried by a glacier, and pushed on its sides (lateral moraines) and front (frontal moraines) or } \\
\text { uncovered when the glacier recesses }\end{array}$ \\
\hline Pampa & High elevation grass-covered wetland formed by lacustrine sediments and organic material layered with heterogeneous colluvium \\
\hline Polythermal glacier & glacier with a base partly at melting point, partly frozen \\
\hline Sandur & Wide glacier erosion products (sand and gravel) plains downstream of glaciers frontal moraines. Also called proglacial outwash plain \\
\hline Subglacial hydrology & All water flowing strictly between a glacier or ice-sheet and the ground below it \\
\hline Talus & Periglacial formation, quite steep, at the border of a sandur \\
\hline Temperate glacier & Glacier with a base at melting point (Cuffey and Paterson, 2010; Van Vliet-Lanoë, 2014) \\
\hline
\end{tabular}

groundwater stocks (see definition in Table 1) or the supply of groundwater springs? Those offshore stocks are being increasingly recognised (Post et al., 2013; Vincent and Violette, 2017), but their origins are still speculative. One hypothesis is that a massive recharge happened just after the Last Glacial Maximum (LGM) during the melting of the ice caps. That is why it is of great interest to study present glacier-aquifer interactions and their potential role in the mechanism of deep recharge and formation of offshore fresh groundwater stocks in coastal zones (Section 3).

- How can groundwater mitigate or amplify meltwater-related hazards? Indeed, concerns emerge about the frequency and amplitude of floods (Favier et al., 2008) and landslide hazards (Huggel et al., 2012), as well as in the potential enhancement of seismic activity in volcanic areas (Saar and Manga, 2003) due to groundwater flows change (Section 4).

- How will subglacial hydrologic systems respond to climate change, and what are the potential effects on groundwater hydrodynamics, and on the related water resources? Indeed there is also a social perspective related to climate change, considering that more than one-sixth of the Earth's population (Barnett et al., 2005), mainly in Asia (Himalayas: Kehrwald et al., 2008; Mukherji et al., 2015), North and South America (Andes: Villacis, 2008; Rabatel et al., 2013; Vuille et al., 2018) and Central and Southern Europe, relies on glaciers or seasonal snow packs for their water supply (Barnett et al., 2005; UNEP, 2007). If glacier meltwater contributions will initially increase as the glaciers lose mass, they will ultimately decrease as they shrink (IPCC 5th report, 2014). Thus concerns emerge about the evolution of available water resources for local populations. Will the surface-aquifers interactions mitigate or aggravate this evolution (Hood et al., 2006)? (Section 5).

- The following issues will not be addressed:

- Cold based glaciers: They exist only in truly frigid environments, e.g. parts of the Antarctic (Mikucki et al., 2015) or Svalbard (Hodson et al., 2016), and they have no liquid water inside them or at their base. Hydrogeology in their surroundings, if existing, is totally different to the one existing around temperate glaciers.

- Permafrost: No permafrost is present under temperate glaciers. It might occur in the peri-glacial zone, depending on the elevation and latitude. For example in Iceland permafrost can be expected to occur above $1000 \mathrm{~m}$ asl in the south and $800-900 \mathrm{~m}$ asl in the north and east (Etzelmuiller et al., 2007), and is identified mostly in the northern half of the island.

- Rock glaciers: as their hydrodynamic is very different from ice glaciers.

- Past and present large ice sheets: Large ice sheets which have receded after the Last Glacial Maximum (about 25,000 to 13,000 years BP), like the Large Scandinavian ice sheet (Baltic sea area), or the Laurentide ice sheet (Canada), have left large fresh-groundwater lenses (Large Scandinavian ice sheet: e.g. Pärn et al., 2016; Salamon, 2016; Laurentide ice sheet: e.g. Saby et al., 2016). They will not be reviewed here, given the difference of spatial scale, and thus of dynamic, between large ice sheet and valley glacier (Sterckx et al., 2017). It is to be noted that their existence and dynamic is partly the result of similar processes than glacier-related aquifers. For example the presence of a till aquifer is suggested by Greenwood et al. (2016) in their conceptual model of a palaeo-ice sheet, and enhanced recharge is demonstrated in past climate, e.g. under the last ice sheet in northwestern Germany (Piotrowski, 1997a,b), the European (palaeo) Ice Sheet (Boulton et al., 1995), or the Laurentide (palaeo) Ice Sheet (Person et al., 2007; Saby et al., 2016). Under the Laurentide Ice Sheet, the magnitude of the recharge was greater than at present (McIntosh and Walter, 2005) by up to 10 times (Person et al., 2007).

\subsection{Studies of catchments headed by temperate glaciers, disregarding hydrogeology}

Many studies have focused on glaciers, because at global scale glaciers provide an important storage of freshwater, and thus streams fed by glacier meltwater are quantitatively important.

Worldwide, ice caps and glacier represent a volume of $170,000 \mathrm{~km}^{3}$ (outside Antarctic and Greenland, Huss and Farinotti, 2012) to $241,000 \mathrm{~km}^{3}$ (outside Antarctic and Greenland ice sheets, Radić and Hock, 2010) (see Fig. 1). For instance, the ice caps and glaciers in Iceland contain the equivalent of $3600 \mathrm{~km}^{3}$ of water, equivalent to the precipitation of 20 years (Björnsson and Pálsson, 2008), and the glaciers of the Hindu Kush Himalayas, $>6000 \mathrm{~km}^{3}$ (Bajracharya et al., 2015). In Iceland glaciers provide one third of the country's main rivers discharge (Björnsson and Pálsson, 2008). In the Alps and the Himalayas too the glaciers, along with snow, are a very important source of runoff for many rivers (Alps: Huss, 2011; Himalayas: Koppes et al., 2015a; Mir et al., 2016; Pamirs: Pohl et al., 2017). Discharge is thus maximum during summer, and minimal during the snow accumulation and freezing period (Mir et al., 2016). Glacier and snow meltwater is the primary source of water for local inhabitants, e.g. in the tropical Andes (Vergara et al., 2007; Vuille et al., 2018). Himalayan glaciers feed the 


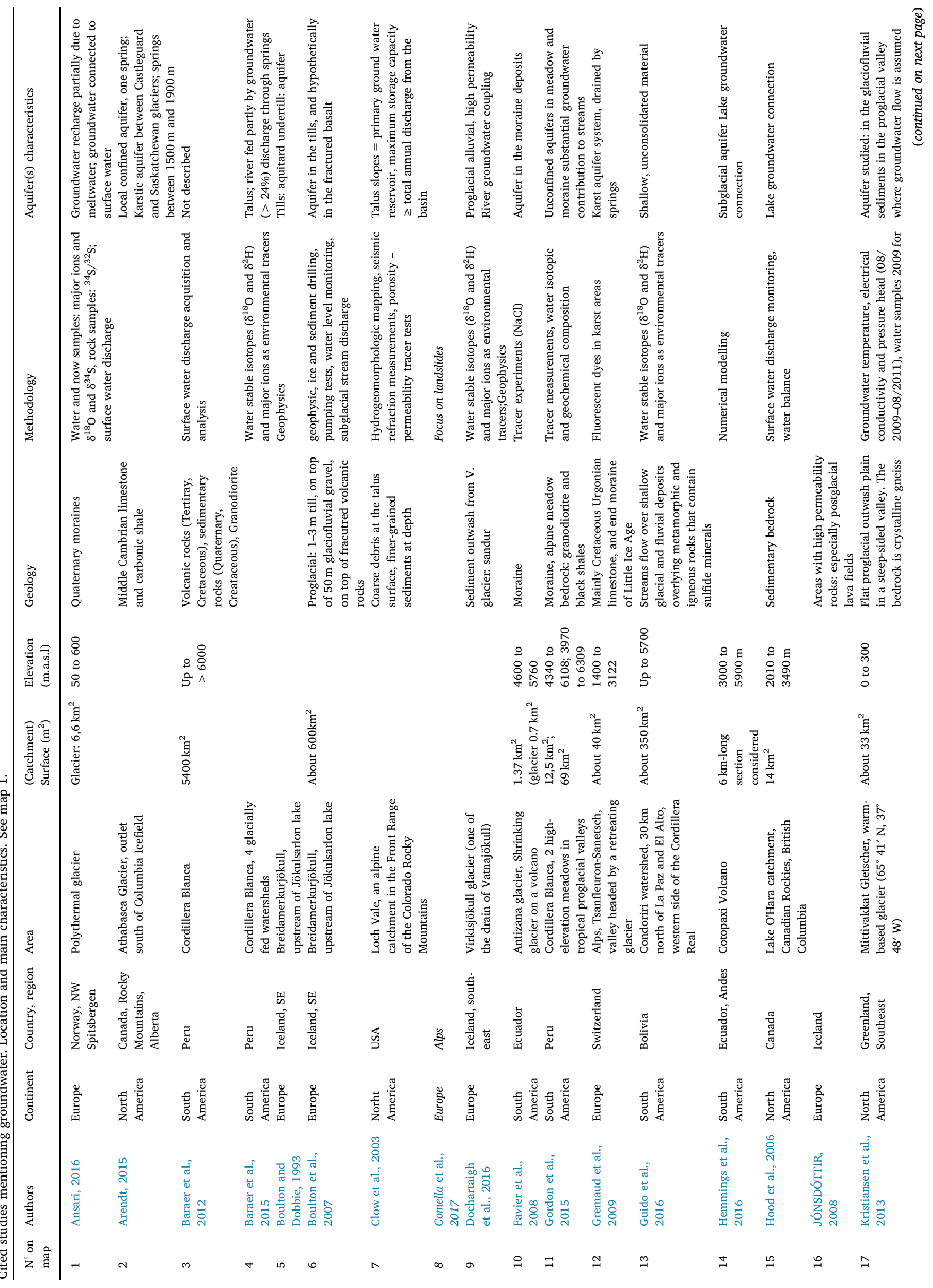




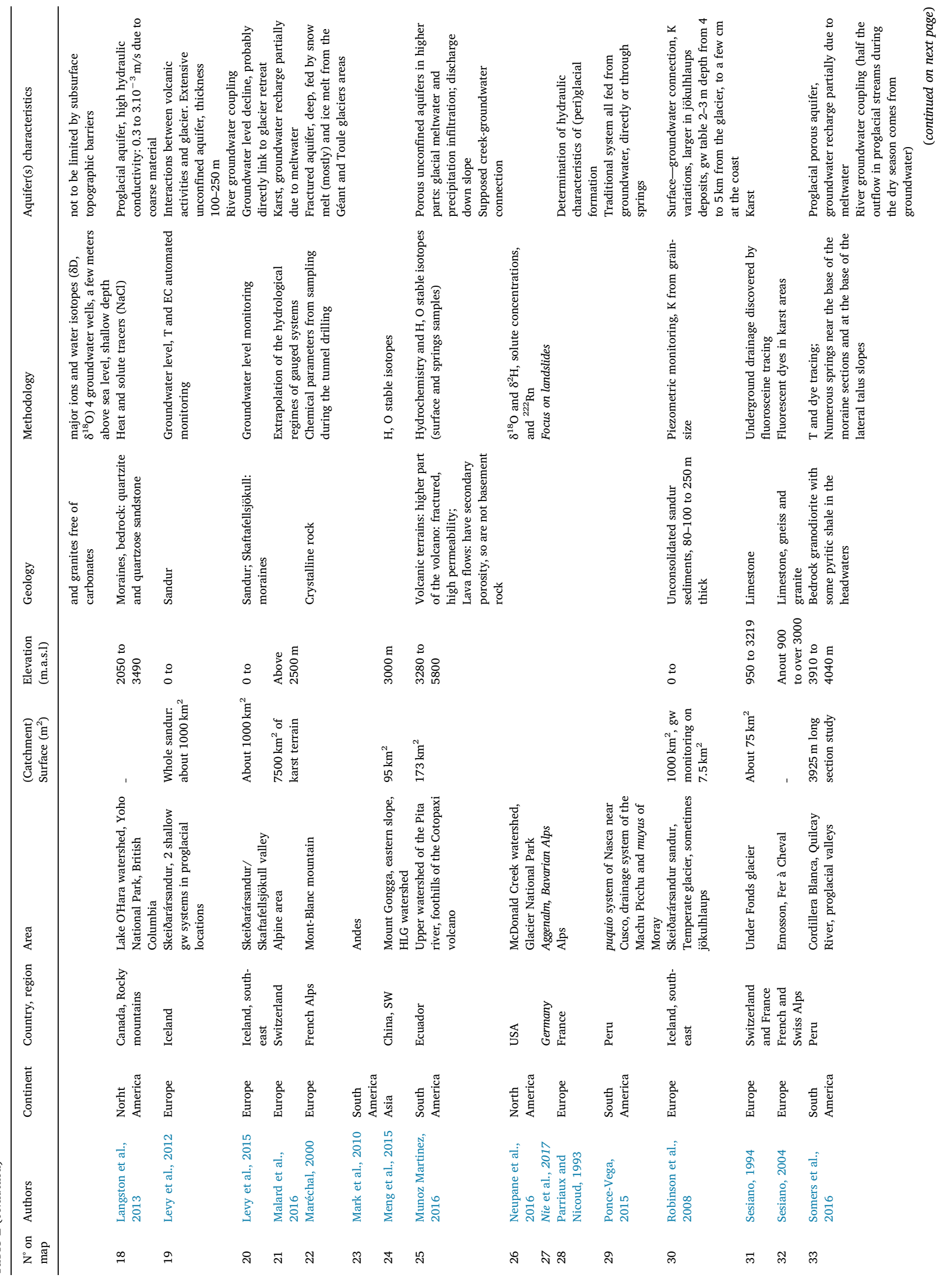




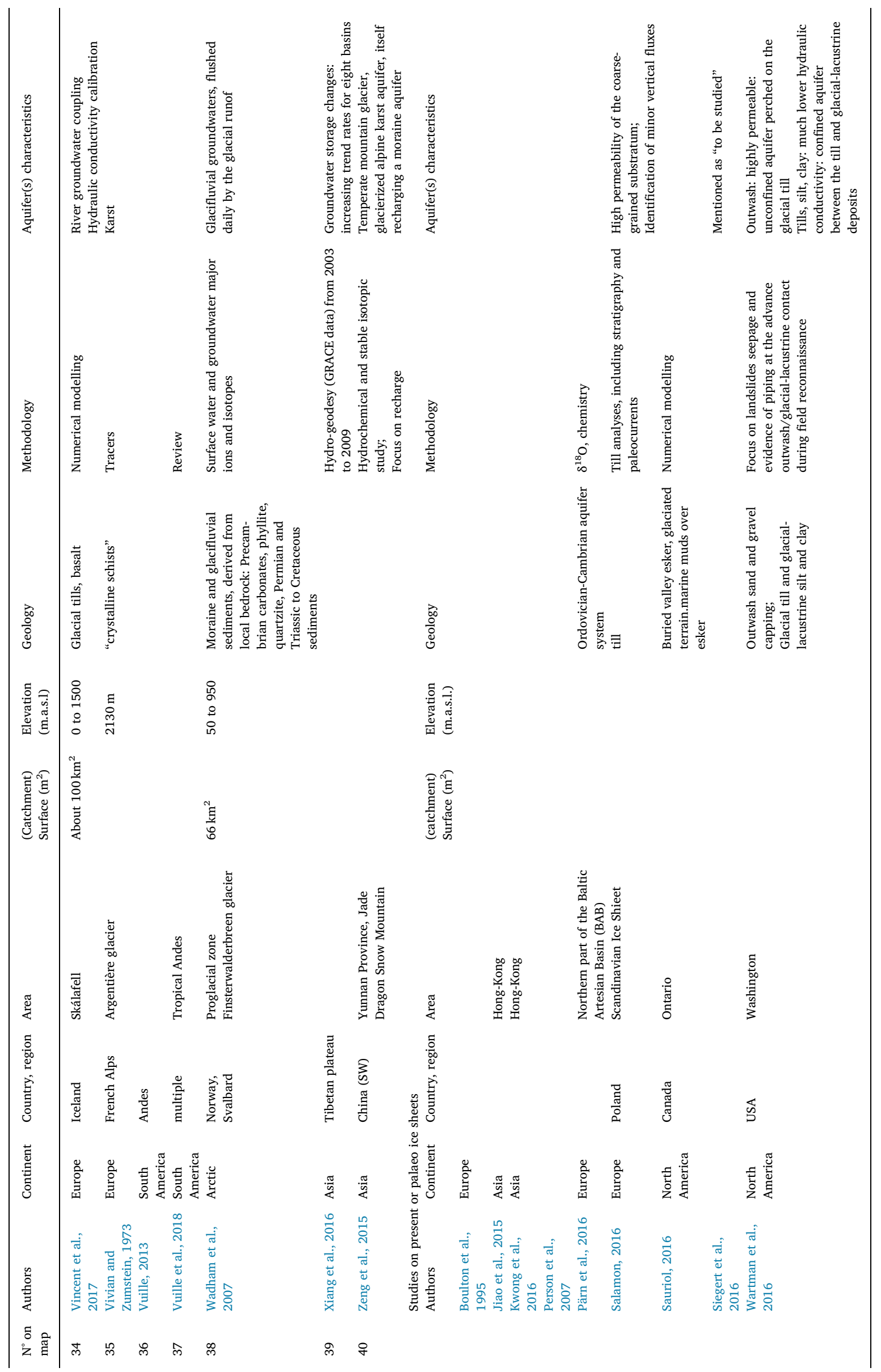




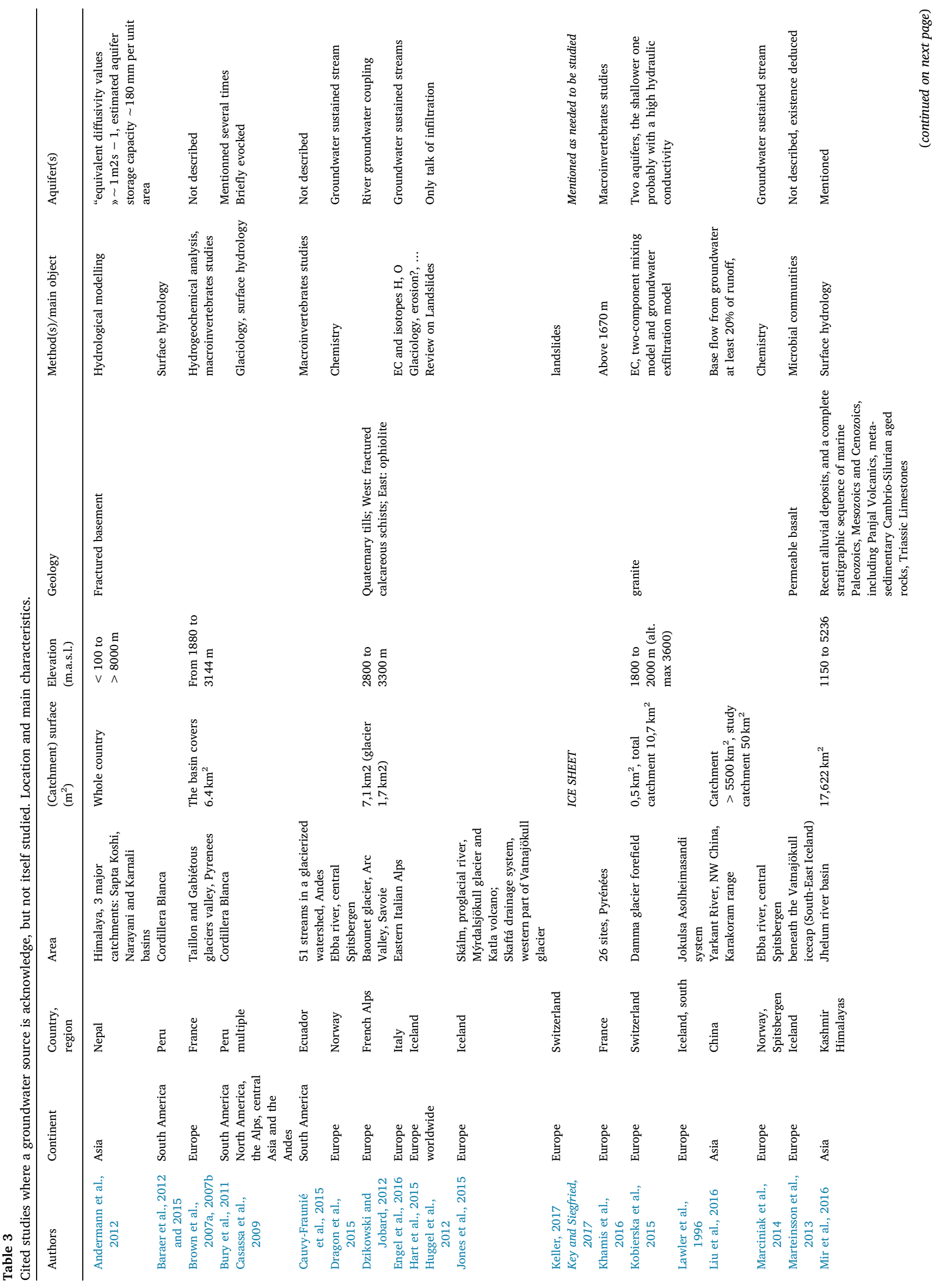


headwaters of the Indus, Ganges and Brahmaputra rivers, which cross some of the most populated areas worldwide (Kehrwald et al., 2008).

For the two last decades, glaciers worldwide have been shrinking at unprecedented rates due to climate change, with few exceptions (e.g. in the Karakoram range and West Himalayas, Mukherji et al., 2015; Schmidt and Nüsser, 2017). The process is most intense in the Himalayas (Kehrwald et al., 2008; Mir et al., 2016) and in the tropical Andes (Rabatel et al., 2013; Somers et al., 2016; Vuille et al., 2018), where some glaciers could disappear in a near future (Barnett et al., 2005; Baraer et al., 2012; Somers et al., 2016). According to an updated glacier inventory of the French Alps, Gardent et al. (2016) report a significant decrease of the overall glacier cover (average loss of $\sim 26 \%$ between the late 60 s and the 2000s). In Iceland, climate change has already lead to the recession of most of the glaciers (Björnsson and Pálsson, 2013), and should lead to a loss of volume of the ice caps of 25 to $35 \%$ within half a century (Björnsson and Pálsson, 2008). The retreat of most of the outlet glaciers of Vatnajökull ice cap is already well documented (e.g. Guðmundsson, 2014; Hannesdóttir, 2014, Hannesdóttir et al., 2015a,b; Storrar et al., 2015; Gudmundsson and Björnsson, 2016; Gudmundsson et al., 2017).

As a consequence of glacier shrinking under climate change, glacial meltwater runoff is expected to first increase (Björnsson and Pálsson, 2008; Casassa et al., 2009; Baraer et al., 2012; Lutz et al., 2014; Ragettli et al., 2015; Azam et al., 2018), and is sometimes already doing so (Gao and Zhang, 2016), but is then expected to decline, and then eventually to disappear with the glaciers (Mark and Seltzer, 2005; Björnsson and Pálsson, 2008; Huss, 2011: Europe; Baraer et al., 2012; Lutz et al., 2014; Clark et al., 2015: Rocky Mountains, USA; Stahl et al., 2008; Casassa et al., 2009; Himalaya: Azam et al., 2018). The runoff peak could be in about 40 years in Iceland (Guðmundsson et al., 2009; Aðalgeirsdóttir et al., 2011), and 35 years in the Himalayas (Lutz et al., 2014; Ragettli et al., 2015; Azam et al., 2018). In the Alps, the glacierised areas contribution to main rivers runoff could decrease by $75 \%$ by the end of the century (Huss, 2011). In the tropical Andes the situation is even more dramatic, with a peak runoff potentially reached in the next 15 years (Asaoka et al., 2014; Ragettli et al., 2015).

Temperate glaciers have an englacial hydrological system (see definition in Table 1), often draining out by a subglacial system, primarily sustained by water flowing from the englacial system, and also supplied by pressure and frictional melting (Björnsson, 1998; Hart et al., 2015). Subglacial systems consist of the connection between channels of different types (see Fig. 2 below; e.g. Röthlisberger, 1972; Hook, 1989; Hock and Hooke, 1993; Walder and Fowler, 1994; Schroeder et al., 2013; Flowers, 2015).

Subglacial channel have been studied in relation to their roles in the glacier movement (Lliboutry, 1968a, 1968b; Kamb et al., 1985), in the erosion processes (e.g. Vivian and Zumstein, 1973; Koppes et al., 2015b), and in relation to outburst floods (Björnsson and Pálsson, 2008).

In theory, subglacial flow includes flow through the till underneath the ice (Hook, 1989; Hart et al., 2015), but most of the glaciological and/or hydrological models and studies of present systems do not take into account groundwater dynamics (Hood et al., 2006; Robinson et al., 2008). Thus unanswered questions remain concerning the role of groundwater: Does this melt volume flow mostly between ice and ground, and increase surface meltwater discharge, or also recharge aquifers? What is the role of groundwater in the water cycle of catchments headed by temperate glaciers? What is the aquifer hydrodynamical response, in time and amplitude, to the onslaught of climate change?

In quite some areas, the role of groundwater is overlooked (e.g. Savéan et al., 2015) or not addressed (e.g. Legchenko et al., 2014 and Garambois et al., 2016) and highlighted as a gap to be dealt with in order to achieve a right and complete understanding of glacierised catchments systems (Hood et al., 2006; Villacis, 2008; Munoz Martinez, 2016; Vuille et al., 2018) and even of ice sheets (Siegert et al., 2016; 


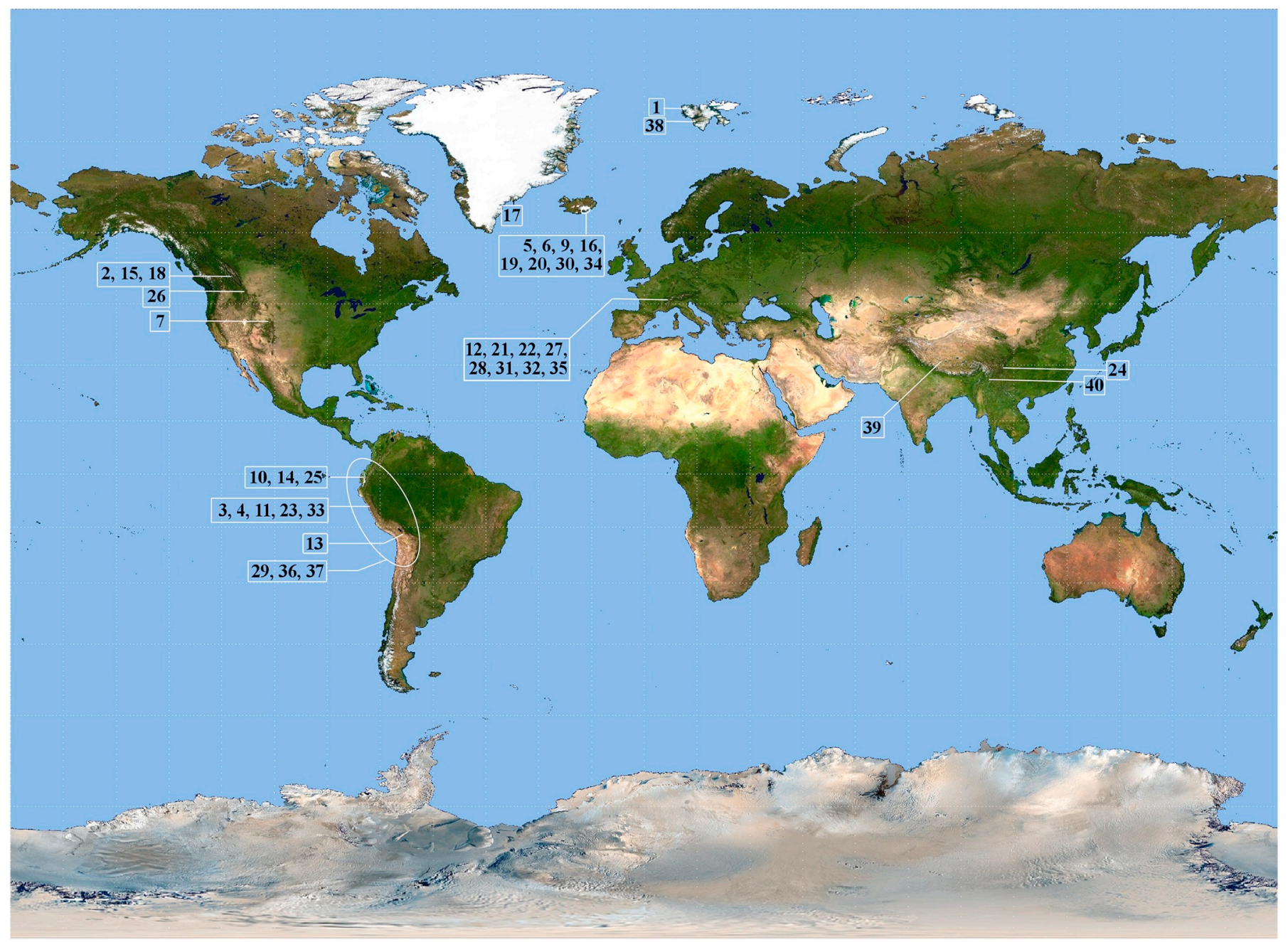

Fig. 1. Map showing localisation of studies concerning glaciers and groundwater (see also Table 2), adapted from a public domain Miller cylindrical projection, from NASA's Earth Observatory « Blue Marble », based on MODIS satellite images. (For interpretation of the references to colour in this figure legend, the reader is referred to the web version of this article.)

Key and Siegfried, 2017), especially in areas with high permeability rocks (Jónsdóttir, 2008). The scientific community recognises the lack of knowledge and research on the glaciers-aquifers interactions and how they will be impacted by climate change (Gremaud et al., 2009; Langston et al., 2013; Baraer et al., 2015; Levy et al., 2015; Somers et al., 2016; Wilson et al., 2016; Vuille et al., 2018). The present review

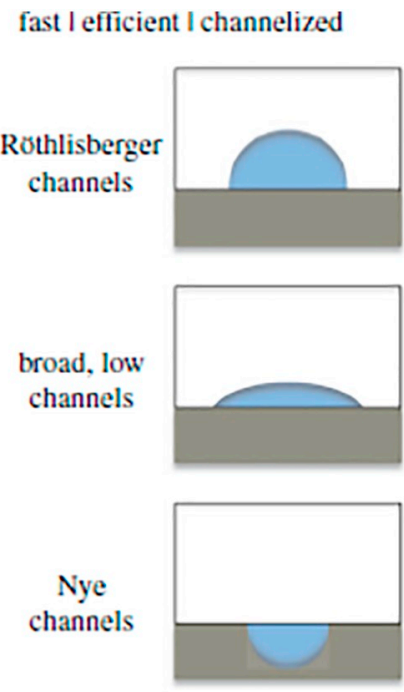

slow I inefficient I distributed

Fig. 2. From Flowers, 2015: Types of sub-glacial channels. 
focuses on this knowledge gap: the particular hydrogeology encountered under and downstream of glaciers, i.e. sub-, pro- and periglacial hydrogeology, and its sensitivity to climate change.

\subsection{Examples of aquifers presence, identified or highly suspected in catchments headed by temperate glaciers (see Tables 2 and 3)}

Some studies demonstrate the existence of sub- or pro-glacial aquifers in catchments headed by temperate glaciers, e.g. in Iceland (Boulton and Dobbie, 1993; Jónsdóttir, 2008; Marteinsson et al., 2013; Levy et al., 2015; Dochartaigh et al., 2016), or in Ecuador (Favier et al., 2008; Hemmings et al., 2016 and Munoz Martinez, 2016), Peru (Cordillera Blanca: Baraer et al., 2015; Gordon et al., 2015; Somers et al., 2016), the US and Canadian Rocky mountains (Clow et al., 2003; Hood et al., 2006; Langston et al., 2013; Arendt, 2015), the French and Swiss Alps (karst systems: Sesiano, 1994; Gremaud et al., 2009; Malard et al., 2016) and other parts of the world (South Greenland: Kristiansen et al., 2013; Svalbard: Wadham et al., 2007). A total of 49 such studies have been found in the scientific literature. See Table 2 and Fig. 1 for an overview and localisation of all studies mentioning aquifers and their hydrodynamic role in glacierised catchments cited in this review, and Table 3 for studies cited in this review where a groundwater source is acknowledged, but not studied itself.

Some studies suggest strong coupling between rivers and the aquifer (Dzikowski and Jobard, 2012; Levy et al., 2012; Somers et al., 2016; Dochartaigh et al., 2016; Guido et al., 2016) and between lakes and the aquifer (Hood et al., 2006), and demonstrate groundwater recharge partially due to meltwater (Somers et al., 2016; Malard et al., 2016; Ansari, 2016). Other expect stronger recharge in the future due to glacier melting (Malard et al., 2016), a consequence of climate change, or demonstrate it in past climates (Person et al., 2007).

\section{Proglacial and subglacial aquifers characteristics}

The few available studies allow to outlines initial information on the interactions of proglacial and subglacial aquifers with surface hydrology (Sections 2.1 and 2.2), and on their hydrodynamic characteristics (Section 2.3).

\subsection{The role of subglacial hydrology in the recharge of aquifers within watersheds headed by temperate glaciers}

What is the role of subglacial hydrology in, the recharge of aquifers within glacierised watersheds? Though this recharge term is very rarely quantified, glacier meltwater is often supposed or identified as a substantial source of recharge for nearby aquifers, either porous, karstic, or fractured:

\footnotetext{
- in porous aquifers (Kristiansen et al., 2013; Munoz Martinez, 2016; Somers et al., 2016), more specifically in alluvial sandur (see definition in Table 1) (Dochartaigh et al., 2016), in talus (see definition in Table 1) (Baraer et al., 2015, see Fig. 3) or in moraine (see definition in Table 1) (Favier et al., 2008; Robinson et al., 2008);

- in karstic aquifers: Sesiano (1994) identified a karstic system under the Fonds glacier (Swiss-French border); Malard et al. (2016) assess that for karst in Swiss alpine areas above $2500 \mathrm{~m}$, recharge is due both to precipitation and to glacier melting; Arendt (2015) acknowledges a karstic aquifer in the Middle Cambrian limestone and carbonic shale under Athabasca Glacier (Canadian Rockies, Alberta, Canada) which is recharged by meltwater from the Columbia Icefield; Zeng et al. (2015) studied a meltwater recharged karstic system in the Yunnan province (China), itself recharging a moraine aquifer;

- and less frequently observed, in fractured aquifers (Maréchal, 2000; Munoz Martinez, 2016).
}

Existence of aquifers can be establish by example because karst outspring does not only reflect the rainfall regime (Gremaud et al., 2009; Malard et al., 2016), or the hydrological and glaciological balances need to integrate groundwater to be indeed balanced (Vincent et al., 2017), or thanks to numerical modelling (Hemmings et al., 2016) or to tracer experiments (Gordon et al., 2015; NaCl: Favier et al., 2008; $\mathrm{NaCl}$ and temperature: Langston et al., 2013; fluorescent dyes in karst areas: Sesiano, 1994, 2004; Gremaud et al., 2009; Somers et al., 2016). Finally water stable isotopes $\left(\delta^{18} \mathrm{O}\right.$ and $\left.\delta^{2} \mathrm{H}\right)$ and major ions are often used as environmental tracers (Kristiansen et al., 2013; Gordon et al., 2015; Baraer et al., 2015; Dochartaigh et al., 2016; Guido et al., 2016; Munoz Martinez, 2016; Neupane et al., 2016; Wilson et al., 2016), to help characterise the aquifers and their flows, to localise recharge and surface-underground coupling areas.

Few values of meltwater recharge to groundwater are estimated, either in the proglacial area or in the subglacial one (Hemmings et al., 2016). Sigurdsson (1990) proposed values for Iceland: 130 to $220 \mathrm{~m}^{3} \cdot \mathrm{s}^{-1}$ (i.e. $2.1 \cdot 10^{-8}$ to $3.4 \cdot 10^{-8} \mathrm{~m} \cdot \mathrm{s}^{-1}$ on $6460 \mathrm{~km}^{2}$, under Langjökull, Hofsjökull, NW and W Vatnajökull, N Mýrdalljökull). Vincent et al. (2017b) estimate the subglacial recharge under Skálafell glacier at $2.2 \cdot 10^{-8} \mathrm{~m} \cdot \mathrm{s}^{-1}\left(685 \mathrm{~mm} \cdot y e a r^{-1}\right)$, representing $85 \%$ of the glacial melt. Meng et al. (2015) evaluate that a third of groundwater in an alpine glacierised region in SW China is derived from ice and snow meltwater. The quantification of meltwater recharge to groundwater in the subglacial and proglacial areas of glacierised areas is one of the key point on which information is lacking.

In many areas under the glacier, meltwater reaching the subglacial system might preferably flow between the ice and the sediment, and infiltrate slowly along the way. The main subglacial channels can drain the subglacial aquifer, as shown by field measurements (Boulton et al., 2007a).

Melting of ice in temperate glacier can occur in various parts of the glaciers: surface melt due to air temperature and the energy balance in general, and bed melt due to pressure and friction (Hart et al., 2015; Saby et al., 2016), and sometimes geothermal energy flux (Lawler et al., 1996; Hemmings et al., 2016; Saby et al., 2016) or volcanic activity (Salamon, 2016).

Increase in glacier melting due to climate change (see Section 1.1), leading to stronger recharge to subglacial aquifer, can be expected in the near future (coming decades), as already suggested by Malard et al. (2016) in an alpine karst system above $2500 \mathrm{~m}$ in Switzerland.

At present enhanced recharge is already observed at a large scale, e.g. by Xiang et al. (2016) on the Tibetan plateau. They observed groundwater storage (GWS) changes through hydro-geodesy (GRACE data) from 2003 to 2009, and noted increasing trend rates in groundwater storage for eight basins. They identified this trend as partly due to more important recharges from meltwater of the glaciers (and also snow-cover and permafrost) especially in the upper parts of the catchment, under the condition of increasing air temperatures. However this method accuracy is sensitive to the estimated ice volume, and estimation till date is quite uncertain for the Himalayas.

\subsection{How intense are the surface-underground water exchanges in catchments headed by temperate glaciers?}

A few studies notice or suggest substantial water exchanges between river and groundwater, i.e. a strong coupling (Dzikowski and Jobard, 2012; Levy et al., 2012; Dochartaigh et al., 2016; Somers et al., 2016), even more in the moraine section of the river (Vincent et al., 2017).

This connection has been put in evidence e.g. through water temperature-tracing techniques, in combination with dye tracing (for the combination of both methods: Somers et al., 2016). Surface water flow can clearly support groundwater level: in Virkisjökull upper sandur (Dochartaigh et al., 2016), during high episodic discharge in the river of Skeiðarársandur, the world largest active sandur, groundwater level increases (Levy et al., 2012), or downstream of Skaftafellsjökull, where 


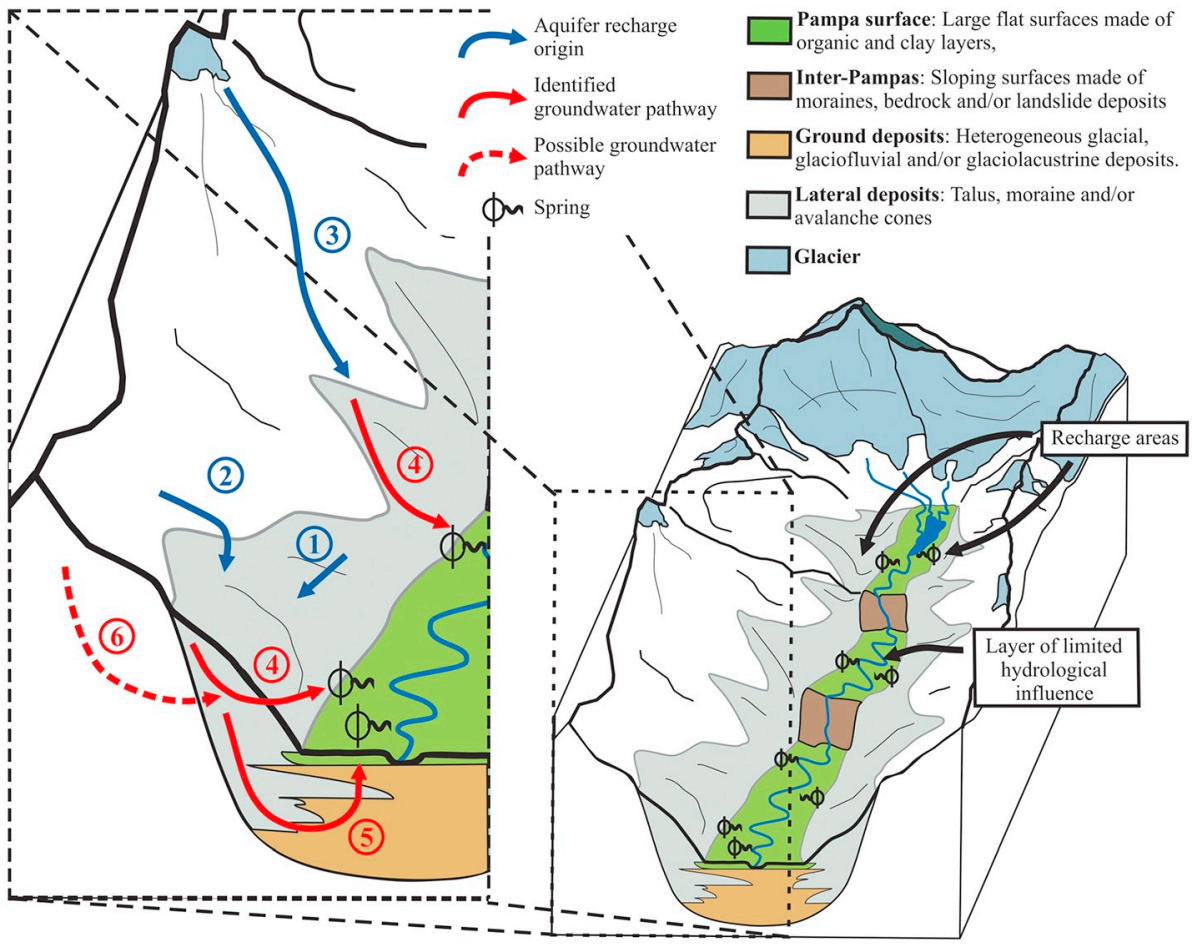

Fig. 3. From Baraer et al., 2015: Conceptual model of the dry season hydrology and spring systems of the glacierised watersheds in the Cordillera Blanca (Ecuador). Recharge and pathway numbers are as follows: (1) direct recharge from precipitation, (2) surface runoff from overlying surfaces, (3) recharge from melt water, (4) flow through the talus slopes, (5) flow through the talus and interconnected glacial deposits, and (6) possible fracture flow through bedrock. fluctuations in groundwater level, temperature and electro-conductivity suggest strong response of the aquifer to changes in river level (Levy et al., 2012, 2015).

As many studies highlight, surface water is fed by groundwater in numerous glacierised catchments (see also Table 3):

- in South America in the Cordillera Blanca (Peru: Baraer et al., 2015, 2 to $10 \mathrm{~km}$ from the glaciers; Gordon et al., 2015; Guido et al., 2016; Somers et al., 2016, at least as far as $8 \mathrm{~km}$ from the glacier outlet), - in North America: McDonald Creek watershed, Glacier National Park (USA, Neupane et al., 2016),

- in the Arctic: Central Spitsbergen, Ebba river (Marciniak et al., 2014; Dragon et al., 2015),

- in Iceland: Virkisjökull lower sandur (about $2 \mathrm{~km}$ from the glacier) (Dochartaigh et al., 2016), and in Skeiðarársandur, by groundwater seepage, and nearby the temperate valley glacier Skaftafellsjökull (Levy et al., 2012),

- in Europe: Taillon glacier valley, French Pyrénées, along with snow melt and glacier ice melt (Brown et al., 2007a, 2007b), in Eastern Italian Alps (Engel et al., 2016) 2 to $10 \mathrm{~km}$ from the glaciers, Damma glacier valley, Switzerland (Kobierska et al., 2015),

- and in Asia: Langtang River basin (Wilson et al., 2016), and 12 other catchments (Andermann et al., 2012) in Nepal, or in Yarkant River, North-West China (Liu et al., 2016).

Most of these studies are geochemical ones, seldom describing geomorphology or any information on the quantification (other than in $\%$ of stream flow) of fluxes.

Oxygen and hydrogen isotopes are used in most of these studies, distinguishing between glacial melt water and groundwater end members. Indeed variations in $\delta^{18} \mathrm{O}$ and $\delta^{2} \mathrm{H}$ allow to distinguish between waters of different origins, and having thus specific isotopic signatures. They are also an interesting tool to study groundwater in glacierised catchments (e.g. Baraer et al., 2015; Meng et al., 2015; Zeng et al., 2015). The local meteoritic line is to be used to check any in between evaporation process. ${ }^{18} \mathrm{O}$ and ${ }^{2} \mathrm{H}$ analyses can thus help identify the sources of the aquifer recharge (glacial melt water, precipitations), and even their respective importance (Meng et al., 2015; Zeng et al., 2015), or estimate the elevation of the recharge (Baraer et al., 2015).

Surface-underground exchanges happen not only between rivers and aquifers, as described above, but also between lakes and aquifers, and subglacial streams and aquifers. Direct connection between glacier meltwater lakes and creeks and groundwater exist as well, e.g. Lake O'Hara in the Canadian Rockies, representative of numerous alpine headwater lakes in the area (Hood et al., 2006), and is formulated as a reasonable hypothesis by Munoz Martinez (2016). Finally the connection of subglacial streams and subglacial aquifers is seen at least in Iceland (field multi-monitoring: Boulton et al., 2007; numerical modelling: Vincent et al., 2017).

\subsection{Aquifers hydraulic characteristics}

The most evident aquifer systems connected to glaciers are in the glacial and peri-glacial formations, i.e. in the first several meters of tills. But aquifers in underlying formations (fractured bedrock) are also important (see Fig. 4). Sub-, pro- and para-glacial tills aquifers are typically coarse-grained, though quite mixed in grain-size and very heterogeneous (Parriaux and Nicoud, 1993; Dochartaigh et al., 2016; Labak-Mechowska, 2016). A study of the formation of till under and near an Icelandic glacier (Hart, 2017) has revealed subglacial clast-rich till: grain size from $<2 \mu \mathrm{m}$ to $>20 \mu \mathrm{m}$, with 2 to $44 \%$ of clay; and in moraines a layer of about $20 \mathrm{~cm}$ of clast-rich till, on top of 2 to $3 \mathrm{~m}$ of a mix of silt, sand and gravel. This is the result of erosion in glacial and periglacial environment, which can reach particularly high rates ( $>10 \mathrm{~mm} \cdot \mathrm{yr}^{-1}$ ) (Koppes et al., 2009; Koppes and Montgomery, 2009; Koppes et al., 2015b).

Some glacial formations tend to have higher hydraulic conductivities (see definition in Table 1) than others: e.g. eskers (see definition in Table 1) formed by subglacial streams (Boulton et al., 2007). When the glacier retreats, eskers can outcrop or become covered by younger sediments.

Consequently the hydraulic conductivity of glacial formation strongly varies, with depth (Ameli et al., 2016), and laterally (Parriaux and Nicoud, 1993), or because of structures such as eskers.

Indeed, specific geological glacial features formed by the glaciers, such as moraines (Parriaux and Nicoud, 1993), eskers and drumlins (see 


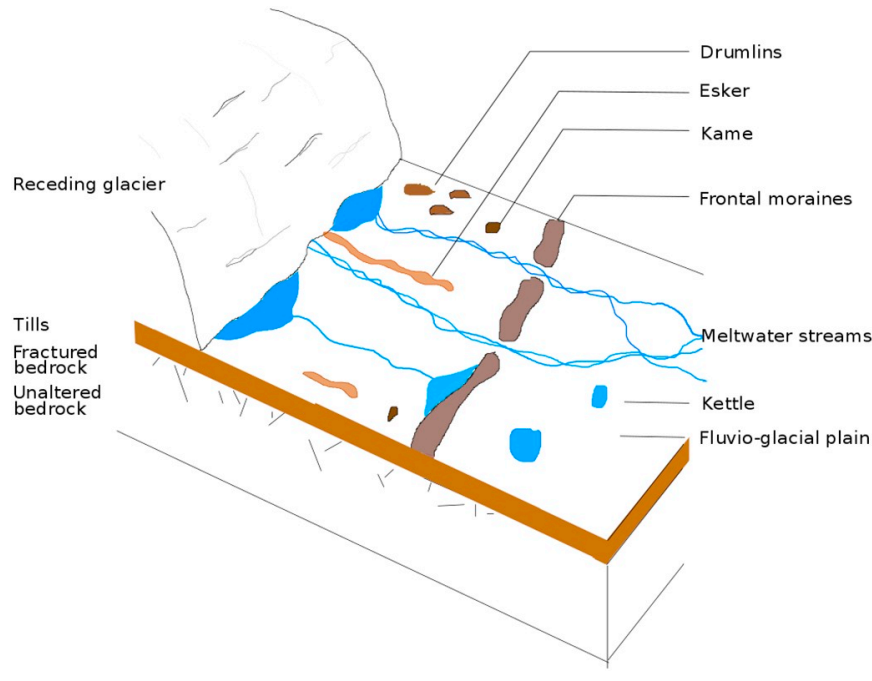

Fig. 4. Schematic glacier-surface hydrology-hydrogeology system, adapted from Benítez (2004) and Hillewaert (2006).

definition in Table 1) are generally good candidates to become aquifers (see Fig. 4). Similarly periglacial features, which often develop, have interesting hydraulic properties, e.g. talus slopes or glacio-lacustrine deltas and fluvio-glacial deposits (including sandur) (Parriaux and Nicoud, 1993) or areas flooded by jökulhlaup (see definition in Table 1). In addition in the Andean area, pampas (see definition in Table 1) also act as groundwater storage entities (Somers et al., 2016).

Despite this heterogeneity, some authors indicate average hydraulic conductivity values for those aquifers (see Table 4). Strictly glacial formations, made by coarse material (i.e. main grain textures belong to gravels, stones and rocks), can be divided into lateral and frontal moraines. Parriaux and Nicoud (1993) give values of hydraulic conductivity about $10^{-6}$ to $10^{-4} \mathrm{~m} . \mathrm{s}^{-1}$ for the lateral moraines, mainly due to poor sorting of the material. They also indicate a total porosity of $15 \%$, and a reduced infiltration capacity due to sharp slopes. For frontal moraines, the range is larger for the total porosity, $15 \%$ to $25 \%$, as well as for the hydraulic conductivity: from $10^{-5}$ to $10^{-4} \mathrm{~m} \cdot \mathrm{s}^{-1}$ (in case of absence of continuity of the permeable layers) to $10^{-2} \mathrm{~m} \cdot \mathrm{s}^{-1}$ (in high mountain areas, with a lot of large rocks in the moraines). Other authors confirm this range for frontal moraines: Boulton et al. (2007a) have measured, through pumping test (texture: mainly sandy gravels), a hydraulic conductivity of $2 \cdot 10^{-5} \mathrm{~m} \cdot \mathrm{s}^{-1}$, and Robinson et al. (2008), through grain-size distribution analysis of slightly gravely muddy sand to sandy gravel, have values from $1 \cdot 10^{-5}$ to $3 \cdot 10^{-4} \mathrm{~m} \cdot \mathrm{s}^{-1}$. Values obtained in specific glacial features tend to be high, and very heterogeneous: in jökulhlaup inundated areas $1.8 \cdot 10^{-3} \mathrm{~m} \cdot \mathrm{s}^{-1}$ (Robinson et al., 2008) and in eskers $4 \cdot 10^{-5}$ to $2 \cdot 1 \cdot 10^{-3} \mathrm{~m} \cdot \mathrm{s}^{-1}$ (Sauriol, 2016).

For one of the main types of para-glacial formations, the sandurs, the hydraulic conductivities values are a little higher in average than in

Table 4

Values of hydraulic conductivity found in the literature for glacial or peri-glacial formations.

\begin{tabular}{ll}
\hline & Hydraulic conductivity (m.s ${ }^{-1}$ ) \\
\hline Lateral moraines & $10^{-6}$ to $10^{-4}$ (Parriaux and Nicoud, 1993) \\
Frontal moraines & $10^{-5}$ to $10^{-2}$ (Parriaux and Nicoud, 1993) \\
& $2 \cdot 10^{-5}$ (Boulton et al., 2007) \\
& $1 \cdot 10^{-5}$ to $3 \cdot 10^{-4}$ (Robinson et al., 2008) \\
& $1.8 \cdot 10^{-3}$ (Robinson et al., 2008) \\
Jökulhlaup inundated areas & $4 \cdot 10^{-5}$ to $2.1 \cdot 10^{-3}$ (Sauriol, 2016) \\
Eskers & $10^{-4}$ to $10^{-2}$ (Parriaux and Nicoud, 1993) \\
Sandurs & $2.2 \cdot 10^{-4}$ (Vincent et al., 2017) \\
& $3.5 \cdot 10^{-4}$ to $3.5 \cdot 10^{-3}$ (Dochartaigh et al., 2016)
\end{tabular}

strictly glacial formation, because of the well sorted material of the tills: $10^{-4}$ to $10^{-2} \mathrm{~m} \cdot \mathrm{s}^{-1}$ according to Parriaux and Nicoud (1993), and $3.5 \cdot 10^{-4}$ to $3.5 \cdot 10^{-3} \mathrm{~m} \cdot \mathrm{s}^{-1}$ according to Dochartaigh et al. (2016), and $2.2 \cdot 10^{-4} \mathrm{~m} \cdot \mathrm{s}^{-1}$ by numerical modelling calibration (Vincent et al., 2017). Parriaux and Nicoud (1993) complete their description with a total porosity from 15 to $20 \%$, and a high infiltration capacity.

Most of the sub- and periglacial aquifers described in the literature are thus in geological formations which are the direct product of glaciers, but the underlying formations are seldom mentioned (e.g. Kobierska et al., 2015) and even more rarely characterized, which is an important knowledge gap.

\subsection{Biodiversity in surface and ground waters in glacierised catchments}

Only a few studies exist about hydrobiology of glacial streams (Wadham et al., 2007; Brown et al., 2007a,b, 2015; Cauvy-Fraunié et al., 2015; Khamis et al., 2016; Robinson et al., 2016; Windsor et al., 2017), and about subglacial biology (Marteinsson et al., 2013; Górniak et al., 2016).

Authors of those publications have mainly used physicochemical methods (Robinson et al., 2016), and macroinvertebrates studies (Brown et al., 2007a,b; Cauvy-Fraunié et al., 2015; Khamis et al., 2016; Windsor et al., 2017), or other biological indicators (Robinson et al., 2016; Marteinsson et al., 2013).

The biological activity in glacial catchments is of great interest, because different sources of water in glacial valleys streams (meltwater or groundwater) lead to different chemical and physical (e.g. bed stability) conditions, and thus to variability in biodiversity (e.g. Khamis et al., 2016). Groundwater fed streams in glacial valleys can even be considered aquatic biodiversity hotspots (Windsor et al., 2017) in otherwise "harsh" environment (Cauvy-Fraunié et al., 2015). The intermittent runoff in streams is another important factor of a particular biodiversity (Robinson et al., 2016). Groundwater-fed kettle lakes could also be of potential ecological significance (Robinson et al., 2008).

Biodiversity in glaciated catchments is particularly sensitive to climate change because of the coupling between glaciers, hydrology and hydrogeology (Brown et al., 2007a; Khamis et al., 2016; Windsor et al., 2017). As previously discussed, the shrinking of glaciers will lead ultimately, after a runoff peak, to the decline of meltwater contribution to streams, and consequently to more homogeneous river habitats, as there will be much less meltwater-dominated streams, and more mix facies (groundwater and meltwater) (Brown et al., 2007a; Khamis et al., 2016), and thus a more homogeneous aquatic fauna (Cauvy-Fraunié et al., 2015; Khamis et al., 2016), with most probably the loss of specialized species in glacier meltwater-fed streams (Cauvy-Fraunié et al., 2015; Khamis et al., 2016).

Moreover the retreat of glaciers would mean reduced recharge to groundwater, as often precipitation is smaller than the previous meltwater recharge rate, and thus streams fed by only meltwater would disappear, and streams fed partially by groundwater could change from permanent to intermittent (Windsor et al., 2017). Flow permanence is, as demonstrated by Windsor et al. (2017), essential for abundance, taxonomic richness and structure of macro invertebrates community. Change in groundwater recharge will also impact lakes levels in sandur plains, which is expected to have negative consequences on its biodiversity (Levy et al., 2015).

Microbial activity could be used as a tracer of subglacial water. Indeed subglacial biological activity has been documented, e.g. by Marteinsson et al. (2013) in subglacial lakes beneath the Vatnajökull ice cap (South-East Iceland), and by Górniak et al. (2016) in South-West Spitsbergen (Arctic). Drilling $>100 \mathrm{~m}$ through the ice enabled Marteinsson et al. (2013) to take samples in two subglacial lakes, in addition to samples taken from a jökulhlaup, and a former subglacial lake, now exposed to the atmosphere. They concluded that five bacterial taxa dominate, and are widely distributed beneath the ice.

How these microorganisms have disseminated under the ice and 
arrived into the subglacial lakes is still unknown, but their wide distribution suggests an underground source (Marteinsson et al., 2013); an underlying aquifer might connect the subglacial lakes (Marteinsson et al., 2013).

\section{What are the effects of glacial meltwater runoff on the supply of groundwater springs or on offshore groundwater stocks?}

Sub-, pro- and periglacial aquifers can discharge either to the surface hydrological system, to a regional continental aquifer system, or to an offshore aquifer system.

In the literature available, there are mostly examples of discharge to the surface drainage system (see Section 2.2). Discharge from groundwater to surface drainage system can happen through springs, but also directly into rivers or lakes, or both. For example Dochartaigh et al. (2016) have documented in Southeast Iceland extensive groundwater discharge to a river throughout the year, particularly across the lower sandur, and during winter. Several cases of discharge from groundwater through terrestrial springs are documented, in the Rocky mountains (Clow et al., 2003; Arendt, 2015), in the Andes (Gordon et al., 2015; Somers et al., 2016), and in the Alps (Gremaud et al., 2009).

Sub-, pro- and periglacial aquifer systems can also discharge into other terrestrial aquifers or to offshore aquifers. It seems indeed plausible that some proglacial hydrogeological aquifers, for example in Iceland, discharge into the sea through marine springs, but none is documented in the consulted literature, other than as a potential hypothesis (Jónsdóttir, 2008). Many sandur aquifers in southeast Iceland discharge offshore (e.g. in Skeiðarársandur at $2.5 \mathrm{~m}^{3} . \mathrm{s}^{-1}$ Robinson et al., 2008; in Skálafell at $0.5 \mathrm{~m}^{3} . \mathrm{s}^{-1}$, Vincent et al., 2017), but it is so far unknown if it is through springs into the ocean or into an offshore underground system. Fig. 5 is a put forward conceptual model of these systems, based on observations and numerical modelling.

Offshore fresh groundwater stocks in littoral areas are being increasingly recognised (Post et al., 2013; Vincent and Violette, 2017), but their origins are still speculative.

Following the work of Kooi and Groen (2001), Post et al. (2013) conducted a thorough review of offshore freshwater occurrences, i.e. important aquifers beneath the sea floor of continental shelves, around the world. The review demonstrated that there is a possibility for the saline/freshwater demarcation surface to be located further than the coastline, most frequently for confined aquifers. They even show that this is a frequent configuration, considering bodies at least $1 \mathrm{~km}$ long and with Total Dissolved Solids $<10 \mathrm{~g} / \mathrm{L}$. Studies on such systems are developing e.g. the offshore groundwater stock suggested by observations and numerical modelling and flux estimation in the Vanur aquifer, south-east India (Vincent and Violette, 2017), or the geophysical profiling establishing evidence of an offshore fresh groundwater system in the southwestern waters of Hong Kong (Jiao et al., 2015; Kwong and Jiao, 2016; Kwong et al., 2016).

Present offshore fresh groundwater stocks could be the relics of periods when glaciers were more extended (Kwong et al., 2016) and recharge more important due to glacial meltwater (Baltic Artesian
Basin, Pleistocene: Haldorsen et al., 2016; Baltic Artesian Basin under the Scandinavian Ice Sheet: Pärn et al., 2016). The concerned periods could either be recent (e.g. the Little Ice Age) or more ancient (Pleistocene), like the Last Glacial Maximum (LGM). Indeed, as shown above, recharge from subglacial meltwater was more important then, enabled by the quantity of meltwater, and by the hydraulic characteristic of sedimentary aquifers (Boulton et al., 1995; Pärn et al., 2016).

The LGM period was particularly favourable to the formation of groundwater stocks, as it offered moreover perfect conditions for another potential process: enhanced meteoric (i.e. by precipitation) recharge at low eustatic levels (Groen et al., 2000; Post et al., 2013). Kwong et al. (2016) present in most of the identified stocks are sequestered in relict fluvial systems during glacial periods. In the case they have studied, during the LGM, sea level was about $130 \mathrm{~m}$ below present sea level, which meant "the coastline receded approximately $120 \mathrm{~km}$ to the south of Hong Kong". Specific geological features can (relatively) protect an aquifer from seawater intrusion, e.g. volcanic dykes (Comte et al., 2017), or thick clay layers (Kwong et al., 2016), or both (Vittecoq et al., 2015).

\section{How can groundwater flow mitigate or amplify water hazards related to glaciers?}

Glacier meltwater plays a role in creating or maintaining natural hazards. As climate change will probably impact pro-, peri- and subglacial aquifers, it will likely affect the water-related natural hazards. Here the focus is on the role of peri- and sub-glacial groundwater in those hazards, i.e. how can the groundwater mitigate or amplify water hazards related to glaciers? The question is of high importance, as many inhabited areas are vulnerable to glaciers related hazards, e.g. the Alps, the Andean range, the Himalayas and Iceland.

In glacierised catchments several kinds of natural hazards can occur. Because of the effects of climate change, concerns emerge about the frequency and amplitude of flooding and landslide hazards, which are discussed in the following sections. Other hazards can also occur like the potential enhancement of seismic activity due to groundwater recharge should also be considered (Costain et al., 1987a,b), especially in the case of interactions of subglacial groundwater and volcanoes (Favier et al., 2008). Indeed earthquake triggered by groundwater recharge variations are documented, e.g. at Mt. Hood, Cascade volcanic arc, Oregon, USA (Saar and Manga, 2003; see also in the Swiss Alps, Roth et al., 1992; in Alaska, Wolf et al., 1997). The process involved is changes in pore-fluid pressure, which affects the stability of faults in volcanic areas (Saar and Manga, 2003).

Finally hydrothermal explosions can be triggered by the interactions between a glacier, the surface and groundwater, and a geothermal or volcanic system (Favier et al., 2008; Montanaro et al., 2016).

\subsection{Flooding}

Floods downstream of glaciers are often provoked by the glacier melting, generally during summer (Sikorska et al., 2015). Named

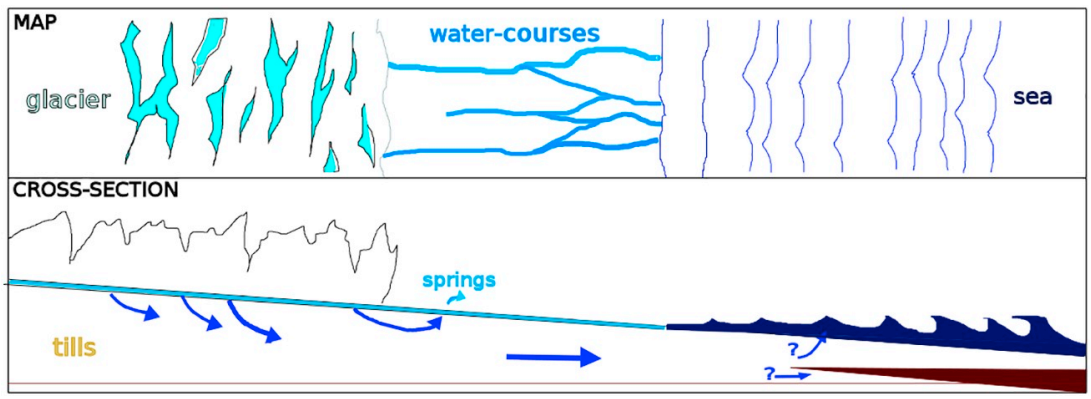

Fig. 5. Conceptual model of glacier-aquifer systems in the southeast of Iceland. 
glacier-melt floods, they are one of the several kinds of floods that can occur in mountainous catchments, the others being generated by precipitations and snow melting (Sikorska et al., 2015). Floods, downstream of glaciers, can also have slightly different processes, leading to: glacial lake outburst flood events, sometimes acronymed GLOFs; jökulhlaups (definitions of GLOFS and jökulhlaups overcross each other), in which groundwater could sometimes play a role; and purely groundwater-driven floods.

- GLOF: Glacial Lake Outburst Floods are due to the rupture of a moraine dam (Mukherji et al., 2015; Zhang et al., 2015), or the heavy subglacial drainage of an ice-dammed lake (Schwalbe and Koschitzki, 2016). Glacial retreat impact the size of glacial lakes (proglacial, englacial or subglacial ones), which will have for consequence more frequent GLOF events. Cases of those can be found in the Himalayas (Zhang et al., 2015 and Mukherji et al., 2015); in Patagonia (Schwalbe and Koschitzki, 2016); or in the Alps, e.g. the closely surveyed Tête-Rousse glacier (Garambois et al., 2016) where preventive pumping was successful (Legchenko et al., 2014). The study of 12 of those lakes from 1974 to 2014 in central west Himalayas by Zhang et al. (2015), through satellite data, confirms the link between the warming of the local climate and the expansion of the lakes, leading to an outburst flood, and 3 lakes at high risk due to it.

- Jökulhlaups include the outburst floods of ice-dammed lakes (e.g. in Switerland, Gornergletcher site: Werder and Funk, 2009; Werder et al., 2009, 2010), as well as the ones provoked by geothermal fields forming subglacial lakes draining periodically (Mýrdalsjökull glacier: Björnsson et al., 2000; the western part of Vatnajökull glacier: Einarsson et al., 2017), and by the immediate draining of the ice melted by volcanic eruptions (Björnsson et al., 2000; Björnsson and Pálsson, 2008; Jones et al., 2015; Einarsson et al., 2017). They are particularly frequent in Iceland, where $60 \%$ of the glacial area is underlain by active volcanoes (Björnsson and Pálsson, 2008). The consequences of jökulhlaups can be massive, geomorphologically, on the vegetation, and on human infrastructures (Björnsson and Pálsson, 2008).

- Groundwater-driven floods are less well known. However if the aquifer water level rises because of the excessive recharge that occurs during the enhanced melting of glaciers, this level can reach the topographical level and cause flooding. One serious flood in 1998 in Ecuador could be due to groundwater outflow, in interaction with volcanic activity (Favier et al., 2008).

\subsection{Landslides and rock slope failures}

In the context of climate change, the large quantities of water released by glacier retreating, and the thawing of ice and permafrost (both act as stability agents), are likely to trigger more and more frequent landslides and rock slope failures (Huggel et al., 2012). Indeed a greater amount of meltwater will probably lead to an enhanced recharge of aquifers. And enhanced recharge of aquifers can increase the pore water pressure, which is a very important factor in deep-seated landslides (Vallet et al., 2016; Nie et al., 2017), which can trigger or participate to trigger landslides and rock failures (Andermann et al., 2012; Wartman et al., 2016; Keller, 2017; Vallet et al., 2016; Nie et al., 2017). Moreover retreat of glaciers leave behind great amounts of unstable material (Huggel et al., 2012), and the melting of important icemasses leads to debutressing, another landslide trigger (Comella et al., 2017). Groundwater circulation also plays a role in the evolution of deep-seated landslides (Comella et al., 2017).

Landslide frequency is increasing all over the world (Huggel et al., 2012), especially in the Himalayas (Qiu, 2016), and in the Alps (Huggel et al., 2012), where a substantial increase in the frequency of large landslides events has been observed from the 1980s, and where a previous peak in the number of rock slope failures occurred around the 1940s, a period characterized by higher air temperatures (Huggel et al., 2012). Furthermore over longer time scales (the Holocene), more landslides are occurring during warmer and wetter periods in the Alps and in the Himalayas (Huggel et al., 2012, referring to several studies).

A lot remains unknown in regard to landslides: e.g. the deep groundwater in the Himalayas is poorly known, limiting the understanding of landslide risk (Nepal: Andermann et al., 2012).

\section{Water resource evolution in catchments headed by temperate glaciers}

Meltwater is of great interest for human use considering on one hand their low contamination and on the other hand their high potential energy (Favier et al., 2008), and their easy access for mountain populations. Climate change will impact the hydrology of glacierised catchments, and probably pro-, peri- and sub-glacial aquifers. Climate change will then affect the glacier related water resources (springs and meltwater streams), and in some places they already are, for example in the Hindu Kush Himalayas (Mukherji et al., 2015). Will the surface water-aquifers interactions mitigate or worsen this evolution of the available water resource? Somers et al. (2016) suggest that the importance of groundwater as a resource will increase as glaciers shrink. Socio-economic issues are important to address, to understand the impacts of climate change and to conduct efficient adaptation research. This can be done by integrating the groundwater component with regional glacio-hydrological studies and ecological responses, as underlined by McDowell and Koppes (2017). The potential impacts of climate change on domestic water availability will be first addressed, followed by the ones on several economic sectors.

\subsection{Potential social impacts}

Changes, even small, in the climate or environment can have dramatic impact on those whose lives depend on local natural resources. Glacier meltwater is a significant source of recharge for groundwater, from which drinking water is extracted. About one-sixth of the Earth's population relies on glaciers or seasonal snow packs for their water supply (Barnett et al., 2005). For example in South America many communities depend totally or partially on glacier-fed watershed (Cordillera Blanca in Peru, Somers et al., 2016), about 2 million of people in Bolivia (Guido et al., 2016), and in and nearby the Himalayas up to 500 million people (Kehrwald et al., 2008) rely on the high elevation glaciers, some entirely (in Ladakh, Schmidt and Nüsser, 2017). Finally, Himalayan glaciers are headwaters of great rivers including the Indus, Ganges and Brahmaputra rivers (Kehrwald et al., 2008; Mukherji et al., 2015).

Concerns emerge about the evolution of the available water resources for local populations: if glacier meltwater contributions will initially increase as the glaciers lose mass, it will ultimately decrease as they shrink, down to a cease of surface flow in the most dramatic cases (Aðalgeirsdóttir et al., 2006; Guðmundsson et al., 2009; Aðalgeirsdóttir et al., 2011). Groundwater resources might be affected too. Indeed in Iceland, Levy et al. $(2012,2015)$ have already presented changes in discharge and stream levels in Skaftafellsjökull valley, but also in Skeiðarársandur, where lake levels have lowered dramatically, losing at least a third of their surface and sometimes drying up completely between 1986 and 2012 (mostly after 1997), and groundwater level has declined up to nearly $2 \mathrm{~m}$ from 2000 to 2012 (no monitoring before). The situation is particularly critical in many Andean catchments, as glaciers retreat already reduces surface water resources coming down from glaciers and high elevation mountains, in areas where populations depend on them (Vergara et al., 2007; Baraer et al., 2015; Munoz Martinez, 2016; Guido et al., 2016; Somers et al., 2016). Valleys downstream of small glaciers will particularly be impacted, and in Bolivia for example, most glaciers are small $\left(<0.5 \mathrm{~km}^{2}\right.$, Guido et al., 2016). Some springs used for domestic needs have already disappeared 
(Mark et al., 2010; Baraer et al., 2015), but some could maybe be sufficient as a resource to replace stream water (Baraer et al., 2015).

Although some of the potential impacts of groundwater flux changes under climate change are mentioned in the scientific literature, they have not been studied in detail. Furthermore the role of groundwater as a water resource is probably going to increase (Kristiansen et al., 2013; Dochartaigh et al., 2016; Somers et al., 2016). For both these reasons, more systematic studies of groundwater in glacierised catchments should be carried out. The revival and strengthening of traditional knowledge and water management techniques could also be helpful (Ponce-Vega, 2015) to mitigate potential social impacts.

\subsection{Potential economic impacts}

Glacier meltwater is also a significant source of energy and a natural resource for local economy, which are thus endangered by climate change. We can expect impacts on different economic activities using water, as detailed in the following paragraphs. Even if the use of surface meltwater is generally predominant, the consequences on groundwater have to be considered.

\subsubsection{Agriculture through irrigation}

Glacial meltwater is used for irrigation mainly in three regions: the Himalayas, the Andes and the Alps.

In the Himalayas, springs that recharge partly by snow melt and glacier melt are used for irrigation in Ladakh (Sudan and McKay, 2015), or Nepal (Poudel and Duex, 2017), or Karakoram (Liu et al., 2016). In Nanga Parbat (Pakistan, Nüsser and Schmidt, 2017) channels divert meltwater for irrigation. Moreover the rivers in the two very large irrigated areas of the Indo-Gangetic and North China plains are supported by the snow-and-glacier-melt rivers of the Hindu Kush Himalayas (Mukherji et al., 2015).

In the Andes surface glacial meltwater sustains farming in the Cordillera Blanca valleys and commercial agriculture lower in the watershed (Peru, Somers et al., 2016). Groundwater is now virtually unexploited in Peru but historically it was (Ponce-Vega, 2015). The puquio system of Nasca, drainage system of the Machu Picchu and muyus of Moray, were all fed from groundwater, directly or through springs.

In the Alps, examples of irrigation from glacial meltwater exist in Switzerland's Rhone Valley, where for hundreds of years, streams fed by meltwater were diverted for irrigation ("bisses" system: Grove and Grove, 1990; Reynard, 1995), and in the Upper Po basin (Ravazzani et al., 2015), where numerous channels made, a long time ago, are still distributing water. But the coming climate changes could cut their role, and lead to smaller crop yields. However, the (winter) precipitation is supposed to increase, and might be stored in the aquifers, creating a new storage capacity for the water (Ravazzani et al., 2015).

Present irrigation systems in glacierised catchments in the Himalayas, the Andeans or the Alps use mostly surface water, which is often partly fed by groundwater, and also groundwater emerging in springs. Thus, the evolution of pro-, peri-, and sub-glacial groundwater are of interest for the future of irrigation both directly, and as a potential replacement for decreasing meltwater. To lessen the effects of decreasing meltwater, the following options can be explored: reactivation of historical groundwater systems (Ponce-Vega, 2015), community implication and education (Mukherji et al., 2016), or small artificial glaciers (Ladakh, India: Norphel, 2009). Small artificial glaciers are created by channelising stream water toward small dams near the villages in the autumn. The water stored, turn to ice during winter, and melt in the spring several weeks before the natural glaciers, higher in elevation.

\subsubsection{Energy: impacts on hydropower production}

All the activities mentioned in this Section 5.2.2 use surface glacial melt water, but any overexploitation of it, or change in surface flow due to climate change, will make study of local groundwater necessary.
Local groundwater stock could be impacted by chain reaction, but could also turn out to be an interesting substitution solution.

Natural storage of discharge in form of ice and snow in mountainous or high latitude areas have a large potential for hydropower: estimations made in Iceland suggested a potential of $187 \mathrm{TWh} /$ year (Jónsdóttir, 2008, from topographical and runoff map), and of $500 \mathrm{GW}$ in the Hindu Kush Himalayas region (Mukherji et al., 2015).

Thus, many hydroelectric plants are established in mountainous area to use snow and glacial meltwater (e.g. Jóhannesson et al., 2011; on the river Jhelum in Kashmir Himalaya, Mir et al., 2016). Hydropower provides $80 \%$ of energy in Peru and $50 \%$ in Ecuador (Vergara et al., 2007), of which $10 \%$ is provided by the dams in the Cordillera Blanca (Somers et al., 2016; Bury et al., 2011). Many more dams are planned over the next 20 years in all the Andean area, mainly for hydropower (Finer and Jenkins, 2012; Tinoco and Kondolf, 2017), with no analyses of potential ecological and social consequences (Tinoco and Kondolf, 2017; Finer and Jenkins, 2012). In Switzerland, hydropower represents $50 \%$ of the total annual electricity production, and is dependent on glacier and snow-melt (Schaefli et al., 2016). One of the dams in the Upper Po basin (Italy, Ravazzani et al., 2015) derives water supply from the ice-melt of two glaciers. In all those cases, glacier shrinking will first lead to an increase in runoff, but then to a substantial decrease, which might affect the performances of hydropower production. Vergara et al. (2007) estimate a diminution of power production by 11 to $15 \%$ on the Rio Santa in Peru. In the cases where runoff will increase for quite some years, it will not necessary lead to much more power production, as the reservoir capacity of the stations are not designed for such runoff (Sveinsson et al., 2010). The electricity produced is sometimes used on site for industrial activities, e.g. aluminium production in Iceland (Krater and Rose, 2009; Bloxsome and Óskarsdóttir, 2017).

Water shortage can cause conflicts between different uses, such as in Peru in 2008 between farmers and a hydroelectricity company (Vuille, 2013; Somers et al., 2016).

Glacial melt-water is also used for other economic activities: some industries (e.g. in the Andes, Somers et al. (2016); bar turning (processing of revolution items) in the French Alps, Arve valley, Gide and Houssel, 1992), and tourism. This last sector implies an increasing pressure on water resources for accommodation in many regions, and for ski resorts, in the Alps. Alpine ski resorts use artificial snow on a regular basis. This technique is highly water and energy consuming, and is used more and more as natural snow coverage is declining. The snow-making costs (snow guns, high-elevation reservoirs) are covered by the resorts, and supported by local government (see for example Auvergne-Rhône-Alpes region Mountain Plan, 2016). Of less significance but worth mentioning here is glaciers also have an added marketing interest in the form of bottled drinking water, which is being marketed in many northern countries.

\section{Conclusion and research perspectives}

The water cycle in catchments headed by temperate glaciers is crucial as a resource for many populations, and is strongly affected by climate change. It also plays a central role in many natural hazards. The role of groundwater has long been the neglected part of this water cycle in scientific studies and management plans. But overlooking the study of groundwater is a hindrance to an effective response to the challenges which have and will have to be dealt within catchments headed by temperate glaciers and downstream of them around the world.

Numbers of aquifers have been identified in catchments headed by temperate glaciers. Some of them have been studied, revealing the following features:

\footnotetext{
- The importance of glacial melt-water recharge, both sub-glacial and pro-glacial;

- The enhanced melt-water recharge in warmer climates;
} 
- The strong connection between surface water and groundwater;

- The heterogeneity of hydraulic conductivities;

- The high aquifer potential of some typical glacial and peri-glacial formations;

- And the role of groundwater (e.g. through pore water pressure) in landslides triggering.

The main knowledge gap identified in this review is the lack of information on the particular hydrogeology (aquifer characteristics and dynamic) encountered under and downstream of glaciers, i.e. sub-, proand peri-glacial hydrogeology, and its role in the catchment dynamic. Several questions should have priority:

- What is the dynamic and quantification of recharge of groundwater by glacial melt-water? And in particular how can sub-glacial groundwater flow and sub-glacial surface flow be (clearly) described and quantified?

- What are the (respective) roles, and the hydraulic characteristics, of the fractured bedrock and the glacial and peri-glacial formations in the groundwater system?

- Where are the aquifers of catchments headed by temperate glaciers outflowing, and how much are they discharging into e.g. deeper regional aquifer systems or offshore fresh groundwater stocks in littoral zones?

The sensitivity of groundwater fluxes to climate change, and climate change potential impacts in terms of resources and natural hazards, is yet to be addressed in all catchments headed by temperate glaciers. They are of major importance for their populations, in terms of socioeconomic impacts: natural resource availability and security from natural hazards.

To address the gaps in the knowledge of the hydrogeology of catchments headed by temperate glaciers, interdisciplinary research at the interface of climate change, glaciology, geomorphology, surface hydrology, hydrogeology, geosciences and socio-economical sciences is needed. First of all hydrogeological knowledge of glacierised watersheds should be systematised, and connected to the surface and atmospheric components. Indeed while the studies mentioned in this review give a first overview of successful approaches to assess the role of groundwater in pro-glacial contexts and/or glacierised catchments, systematic and comparative studies still have to be done for the understanding of aquifers dynamic and water flux quantification. The gathering of field data such as groundwater level, temperature, electroconductivity, but also location of springs and surface water discharge, as well as hydrodynamic properties (measured thanks to hydraulic tests) will allow characterisation of aquifer systems.

Such data, in addition to the data existing generally (topography, geomorphology, weather) or relatively frequently (surface water), can be used to build and validate comprehensive numerical models, spatially distributed and physically based. These models facilitate better understanding of hydrogeological systems around the world, and allow predicting their response to climate change. Hydrogeological numerical models should test at the minimum the hypothesis of 1-layer (e.g. tills or fractured bedrock) in 2D and 2-layers (e.g. tills and underlying fractured bedrock) aquifers systems in 2D-cross sections or 3D. If extended geological data exist or is acquired, complex geometries can be considered in full 3D. In case of proximity to the coastline, part of the undersea domain should be taken into account to manage the boundary condition with the sea at best, an important one to study the potential formation of offshore ground freshwater stock. And in addition to classic flow equations, the effects of temperature variations on water viscosity and density may be taken into account, although neglecting it in a first approach can be acceptable (Lemieux et al., 2008).

Simulation tools used in existing models of former or present large ice sheets could be evaluated in the glacierised catchments context. However references to those models should be done with caution, as they often consider the sub-glacial flow and part of the groundwater flow as one single component.

Data analysis and numerical runs should particularly look at: (i) Localisation, mechanism, quantification and evolution of the recharge of aquifers during the glacier retreat; (ii) Aquifers discharge (typology and quantification); (iii) Spatial heterogeneity of glacial aquifers hydraulic conductivity; (iv) Groundwater dynamics during and after the retreat of the glacier; (v) Surface-subsurface-deep water exchanges, including the clear distinction and quantification of sub-glacial flow (strictly between the ice and the ground) and sub-glacial groundwater flow.

Application of climate forcing and melt forcing in the models will allow prediction of future conditions, including exploration of the potential future hydrological response to climate.

To enable adequate resource response management and adaptation, sociological studies should also be done. And as a first step toward social reaction and adaptation, a participatory approach could complete the physical one. Indeed the acquisition of data can be an effective way to involve local populations in the understanding and protection of the local water resources. Involvement of local people in field work and data gathering can be considered, such as practised in the "Barefoot Hydrologists" technique (Mukherji et al., 2016). Moreover the participatory approach can lead to the elaboration of several deliverables, to be used for mainstream communication.

The integrative multi-disciplinary approach of research in catchments headed by temperate glaciers should allow to contribute to answer key scientific questions such as the formation of offshore fresh groundwater stocks. This approach will also help to develop optimal management, for a better preservation of natural resources and protection from natural hazards.

\section{Acknowledgements}

Thanks to Jane Hart and Michele Koppes for helpful suggestions, and to Judith D'Souza for an opening on grassroots social sciences, and proof-reading the manuscript.

\section{References}

Aðalgeirsdóttir, G., Jóhannesson, T., Björnsson, H., Pálsson, F., Sigurðsson, O., 2006. Response of Hofsjökull and southern Vatnajökull, Iceland, to climate change: response of glacier in Iceland. J. Geophys. Res. Earth Surf 111, 1-15.

Aðalgeirsdóttir, G., et al., 2011. Modelling the 20th and 21st century evolution of Hoffellsjökull glacier, SE-Vatnajökull, Iceland. Cryosphere 5, 961-975.

Ameli, A.A., et al., 2016. Hillslope permeability architecture controls on subsurface transit time distribution and flow paths. J. Hydrol. https://doi.org/10.1016/j. jhydrol.2016.04.071.

Andermann, C., et al., 2012. Impact of transient groundwater storage on the discharge of Himalayan rivers. Nat. Geosci. 5, 127-132.

Ansari, A.H., 2016. Stable isotopic evidence for anaerobic maintained sulphate discharge in a polythermal glacier. Polar Sci 10, 24-35.

Arendt, C.A., 2015. The Hydrologic Evolution of Glacial Meltwater: Insights and Implications from Alpine and Arctic Glaciers. University of Michigan.

Asaoka, Y., Yoshizawa, K., Kinouchi, T., Umeda, M., 2014. Impact Assessment of Glacier Retreat on Catchment Water Resources in the Tropical Andes, Bolivia.

Azam, M.F., et al., 2018. Review of the status and mass changes of Himalayan-Karakoram glaciers. J. Glaciol 1-14. https://doi.org/10.1017/jog.2017.86.

Bajracharya, et al., 2015. The glaciers of the Hindu Kush Himalayas: current status and observed changes from the 1980s to 2010. Int. J. Water Resour. Dev 161-173. https://doi.org/10.1080/07900627.2015.1005731.

Baraer, M., et al., 2012. Glacier recession and water resources in Peru's Cordillera Blanca. J. Glaciol. 58, 134-150.

Baraer, M., et al., 2015. Contribution of groundwater to the outflow from ungauged glacierized catchments: a multi-site study in the tropical Cordillera Blanca, Peru: CONTRIBUTION OF GROUNDWATER TO GLACIERIZED CATCHMENTS IN C.B., PERU. Hydrol. Process. 29, 2561-2581.

Barnett, T.P., Adam, J.C., Lettenmaier, D.P., 2005. Potential impacts of a warming climate on water availability in snow-dominated regions. Nature 438, 303-309.

https://commons.wikimedia.org/wiki/File:Receding_glacier-en.svg.

Björnsson, H., 1998. Hydrological characteristics of the drainage system beneath a surging glacier. Nature 395, 771-774.

Björnsson, H., Pálsson, F., 2008. Icelandic glaciers. Jökull 58, 365-386.

Björnsson, H., Pálsson, F., Gudmundsson, M.T., 2000. Surface and bedrock topography of the Mýrdalsjökull ice cap, Iceland: the Katla caldera, eruption sites and routes of 
jökulhlaups. Jökull 29-46.

Björnsson, et al., 2013. Contribution of Icelandic ice caps to sea level rise: trends and variability since the Little Ice Age. Geophysical Research Letters vol 40 (8), 1546-1550.

Bloxsome, N., Óskarsdóttir, G.H., 2017. Aluminium in Iceland. Aluminium international today: the journal of aluminium production and processing 30, 28-29.

Boulton, G.S., Dobbie, K.E., 1993. Consolidation of sediments by glaciers: relations between sediment geotechnics, soft-bed glacier dynamics and subglacial ground-water flow. J. Glaciol. 39, 26-44.

Boulton, G.S., Caban, P.E., Van Gijssel, K., 1995. Groundwater flow beneath ice sheets: part I-large scale patterns. Quat. Sci. Rev. 14, 545-562.

Boulton, G.S., Lunn, R., Vidstrand, P., Zatsepin, S., 2007. Subglacial drainage by groundwater-channel coupling, and the origin of esker systems: part 1—glaciological observations. Quat. Sci. Rev. 26, 1067-1090.

Brown, L.E., Hannah, D.M., Milner, A.M., 2007a. Vulnerability of alpine stream biodiversity to shrinking glaciers and snowpacks. Glob. Chang. Biol. 13, 958-966.

Brown, L.E., Milner, A.M., Hannah, D.M., 2007b. Groundwater influence on alpine stream ecosystems. Freshw. Biol. 52, 878-890.

Brown, L.E., Dickson, N.E., Carrivick, J.L., Füreder, L., 2015. Alpine river ecosystem response to glacial and anthropogenic flow pulses. Freshw. Sci 34, 1201-1215.

Bury, J.T., et al., 2011. Glacier recession and human vulnerability in the Yanamarey watershed of the Cordillera Blanca, Peru. Clim. Chang 105, 179-206.

Casassa, G., López, P., Pouyaud, B., Escobar, F., 2009. Detection of changes in glacial runoff in alpine basins: examples from North America, the Alps, Central Asia and the Andes. Hydrol. Process. 23, 31-41.

Cauvy-Fraunié, S., Espinosa, R., Andino, P., Jacobsen, D., Dangles, O., 2015. Invertebrate metacommunity structure and dynamics in an Andean glacial stream network facing climate change. PLoS One 10, e0136793.

Clark, A.M., Harper, J.T., Fagre, D.B., 2015. Glacier-derived August runoff in northwest Montana. Arct. Antarct. Alp. Res. 47, 1-16.

Clow, D.W., et al., 2003. Ground water occurrence and contributions to streamflow in an alpine catchment, Colorado Front Range. Groundwater 41, 937-950.

Comella, P., Francani, V., Gattinoni, P., 2017. Development and control of deep seated gravitational slope deformation: the case of Colzate-Vertova Landslide, Bergamo, Northern Italy. World Acad. Sci. Eng. Technol, Int. J. Environ. Chem. Ecol. Geol. Geophysical Eng 11, 688-698.

Comte, J.-C., Wilson, C., Ofterdinger, U., González-Quirós, A., 2017. Effect of volcanic dykes on coastal groundwater flow and saltwater intrusion: a field-scale multiphysics approach and parameter evaluation: VOLCANIC DYKES AND GROUNDWATER FLOW. Water Resour. Res. 53, 2171-2198.

Costain, Bollinger, Speer, 1987a. Hydroseismicity: a hypothesis for the role of water in the generation of intraplate seismicity. Seismol. Res. Lett 58, 41-64.

Costain, J.K., Bollinger, G.A., Speer, J.A., 1987b. Hydroseismicity-a hypothesis for the role of water in the generation of intraplate seismicity. Geology 15, 618-621.

Cuffey, K.M., Paterson, W.S.B., 2010. The Physics of Glaciers.

Dochartaigh, B.O., et al., 2016. Groundwater-Meltwater Interaction in a Proglacial Aquifer. British Geological Survey.

Dragon, K., Marciniak, M., Szpikowski, J., Szpikowska, G, Wawrzyniak, T., 2015. The hydrochemistry of glacial Ebba River (Petunia Bay, Central Spitsbergen): groundwater influence on surface water chemistry. J. Hydrol. 529, 1499-1510.

Dzikowski, M., Jobard, S., 2012. Mixing law versus discharge and electrical conductivity relationships: application to an alpine proglacial stream: mixing law versus Q-EC relationships from an alpine proglacial stream. Hydrol. Process. 26, 2724-2732.

Einarsson, B., JóHannesson, T., Thorsteinsson, T., Gaidos, E., Zwinger, T., 2017. Subglacial flood path development during a rapidly rising jökulhlaup from the western Skaftá cauldron, Vatnajökull, Iceland. J. Glaciol 1-13. https://doi.org/10. 1017/jog.2017.33.

Engel, M., et al., 2016. Identifying run-off contributions during melt-induced run-off events in a glacierized alpine catchment: identifying run-off contributions in a glacierized catchment. Hydrol. Process. 30, 343-364.

Etzelmüller, B., et al., 2007. The regional distribution of mountain permafrost in Iceland. Permafr. Periglac. Process. 18, 185-199.

Favier, V., et al., 2008. Evidence of groundwater flow on Antizana ice-covered volcano, Ecuador/Mise en évidence d'écoulements souterrains sur le volcan englacé Antizana, Equateur. Hydrol. Sci. J 53, 278-291.

Finer, M., Jenkins, C.N., 2012. Proliferation of hydroelectric dams in the Andean Amazon and implications for Andes-Amazon connectivity. PLoS One 7, e35126.

Flowers, G.E., 2015. Modelling water flow under glaciers and ice sheets. Proc. R. Soc. A Math. Phys. Eng. Sci 471, 20140907.

Fridlund, J., 2017. Analysis of Multicomponent Data to Study Esker Structures, TurkuFinland.

Gao, L., Zhang, Y., 2016. Spatio-temporal variation of hydrological drought under climate change during the period 1960-2013 in the Hexi Corridor, China. J. Arid. Land 8, 157-171.

Garambois, S., Legchenko, A., Vincent, C., Thibert, E., 2016. Ground-penetrating radar and surface nuclear magnetic resonance monitoring of an englacial water-filled cavity in the polythermal glacier of Tête Rousse. Geophysics 81, WA131-WA146.

Gardent, M., Rabatel, A., Dedieu, J.P., Deline, P., Schoeneich, P., 2016. First Results from the New French Alps Glaciers Inventory.

Gide, C., Houssel, J.-P., 1992. Le décolletage dans la vallée de l'Arve: un district industriel face à la mutation contemporaine/The bar turning industry in the Arve Valley (Haute-Savoie): contemporary change in an industrial region. Revue de géographie de Lyon 67, 199-208.

Gordon, R.P., et al., 2015. Sources and pathways of stream generation in tropical proglacial valleys of the Cordillera Blanca, Peru. J. Hydrol 522, 628-644.

Górniak, D., Marszałek, H., Jankowska, K., Dunalska, J., 2016. Bacterial community succession in an Arctic lake-stream system (Brattegg Valley, SW Spitsbergen). Boreal Environ. Res. 21, 115-133.

Greenwood, S.L., Clason, C.C., Helanow, C., Margold, M., 2016. Theoretical, contemporary observational and palaeo-perspectives on ice sheet hydrology: processes and products. Earth Sci. Rev. 155, 1-27.

Gremaud, V., Goldscheider, N., Savoy, L., Favre, G., Masson, H., 2009. Geological structure, recharge processes and underground drainage of a glacierised karst aquifer system, Tsanfleuron-Sanetsch, Swiss Alps. Hydrogeol. J 17, 1833-1848.

Groen, J., Velstra, J., Meesters, A., 2000. Salinization processes in paleowaters in coastal sediments of Suriname: evidence from $\delta 37 \mathrm{Cl}$ analysis and diffusion modelling. J. Hydrol. 234, 1-20.

Grove, A.T., Grove, J.M., 1990. Traditional montane irrigation systems in modern Europe: an example from Valais, Switzerland. Agric. Ecosyst. Environ. 33, 181-186.

Guðmundsson, S., 2014. Reconstruction of late 19th century geometry of Kotárjökull and Breiðamerkurjökull in SE-Iceland and comparison with the present.

Gudmundsson, S., Björnsson, H., 2016. Changes in the flow pattern of Breioamerkurjokull reflected by bending of the Esjufjallarond medial moraine. Jokull 66, 95-100.

Gudmundsson, S., Björnsson, H., Pálsson, F., 2017. Changes of Breiðamerkurjökull glacier, SE-Iceland, from its late nineteenth century maximum to the present. Geogr. Ann. Ser. A Phys. Geogr 99, 338-352.

Guðmundsson, S., et al., 2009. Similarities and differences in the response to climate warming of two ice caps in Iceland. Hydrol. Res 40, 495-502.

Guido, Z., McIntosh, J.C., Papuga, S.A., Meixner, T., 2016. Seasonal glacial meltwater contributions to surface water in the Bolivian Andes: a case study using environmental tracers. J. Hydrol Reg. Stud 8, 260-273.

Haldorsen, S., et al., 2016. Groundwater and Global Palaeoclimate Signals (G@GPS). Episodes 39, 556.

Hannesdóttir, H., 2014. Variations of Southeast Vatnajökull, Past, Present and Future.

Hannesdóttir, H., Björnsson, H., Pálsson, F., Aðalgeirsdóttir, G., Guðmundsson, S., 2015a Changes in the southeast Vatnajökull ice cap, Iceland, between 1890 and 2010 . Cryosphere 9, 565-585.

Hannesdóttir, H., Björnsson, H., Pálsson, F., Aðalgeirsdóttir, G., Guðmundsson, S., 2015b. Variations of southeast Vatnajökull ice cap (Iceland) 1650-1900 and reconstruction of the glacier surface geometry at the Little Ice Age maximum: timing and reconstruction of the LIA maximum of SE-Vatnajökull. Geogr. Ann. Ser. A Phys. Geogr 97 237-264.

Hart, J.K., 2017. Subglacial till formation: microscale processes within the subglacial shear zone. Quat. Sci. Rev. 170, 26-44.

Hart, J.K., Rose, K.C., Clayton, A., Martinez, K., 2015. Englacial and subglacial water flow at Skálafellsjökull, Iceland derived from ground penetrating radar, in situ Glacsweb probe and borehole water level measurements: englacial and subglacial water flow at Skálafellsjökull, Iceland. Earth Surf. Process. Landf 40, 2071-2083.

Hemmings, B., Whitaker, F., Gottsmann, J., Hawes, M.C., 2016. Non-eruptive ice melt driven by internal heat at glaciated stratovolcanoes. J. Volcanol. Geotherm. Res. https://doi.org/10.1016/j.jvolgeores.2016.09.004.

https://commons.wikimedia.org/wiki/File:Receding_glacier-en.svg Creative Commons Attribution-Share Alike 3.0 Unported license.

Hock, R., Hooke, R.L., 1993. Evolution of the internal drainage system in the lower part of the ablation area of Storglaciären, Sweden. Geol. Soc. Am. Bull 105, 537-546.

Hodson, A., Nowak, A., Christiansen, H., 2016. Glacial and periglacial floodplain sedi ments regulate hydrologic transfer of reactive iron to a high arctic fjord: arctic floodplain iron transfer. Hydrol. Process. 30, 1219-1229.

Hood, J.L., Roy, J.W., Hayashi, M., 2006. Importance of groundwater in the water balance of an alpine headwater lake. Geophys. Res. Lett. 33.

Hook, R.L., 1989. Englacial and subglacial hydrology: a qualitative review. Arct. Alp. Res. 21, 221-233.

Huggel, C., et al., 2012. Ice thawing, mountains falling-are alpine rock slope failures increasing? Geol. Today 28, 98-104.

Huss, M., 2011. Present and future contribution of glacier storage change to runoff from macroscale drainage basins in Europe: GLACIER CONTRIBUTION TO CONTINENTAL-SCALE RUNOFF. Water Resour. Res. 47.

Huss, M., Farinotti, D., 2012. Distributed ice thickness and volume of all glaciers around the globe: GLOBAL GLACIER ICE THICKNESS AND VOLUME. J. Geophys. Res. Earth Surf 117, n/a.

IPCC, 2014. $5^{\text {th }}$ report, Climate Change 2014: Impacts, Adaptation, and Vulnerability, Part A, Chapter 3. IPCC.

Jiao, J.J., et al., 2015. Reconstructed chloride concentration profiles below the seabed in Hong Kong (China) and their implications for offshore groundwater resources. Hydrogeol. J. 23, 277-286.

Jóhannesson, T., et al., Thorsteinsson, T., Björnssson, H., 2011. Hydropower, snow and ice. In: Climate Change and Energy Systems. Impacts, Risks and Adaptation in the Nordic and Baltic Countries.

Jones, M.T., et al., 2015. Monitoring of jökulhlaups and element fluxes in proglacial Icelandic rivers using osmotic samplers. J. Volcanol. Geotherm. Res. 291, 112-124.

Jónsdóttir, J.F., 2008. A runoff map based on numerically simulated precipitation and a projection of future runoff in Iceland/Une carte d'écoulement basée sur la précipitation numériquement simulée et un scénario du futur écoulement en Islande. Hydrol. Sci. J. 53, 100-111.

Kamb, B., et al., 1985. Glacier surge mechanism: 1982-1983 surge of Variegated Glacier, Alaska. Science 227, 469-479.

Kehrwald, N.M., et al., 2008. Mass loss on Himalayan glacier endangers water resources. Geophys. Res. Lett. 35.

Keller, B., 2017. Massive rock slope failure in Central Switzerland: history, geologic-geomorphological predisposition, types and triggers, and resulting risks. Landslides. https://doi.org/10.1007/s10346-017-0803-1.

Key, K., Siegfried, M.R., 2017. The feasibility of imaging subglacial hydrology beneath ice 
streams with ground-based electromagnetics. J. Glaciol 1-17. https://doi.org/10. 1017/jog.2017.36.

Khamis, K., Brown, L.E., Hannah, D.M., Milner, A.M., 2016. Glacier-groundwater stress gradients control alpine river biodiversity. Ecohydrology 9, 1263-1275.

Kobierska, F., Jonas, T., Kirchner, J.W., Bernasconi, S.M., 2015. Linking baseflow separation and groundwater storage dynamics in an alpine basin (Dammagletscher, Switzerland). Hydrol. Earth Syst. Sci. 19, 3681-3693.

Kooi, H., Groen, J., 2001. Offshore continuation of coastal groundwater systems; predictions using sharp-interface approximations and variable-density flow modelling. J. Hydrol. 246, 19-35.

Koppes, M.N., Montgomery, D.R., 2009. The relative efficacy of fluvial and glacial erosion over modern to orogenic timescales. Nat. Geosci. 2, 644-647.

Koppes, M., Hallet, B., Anderson, J., 2009. Synchronous acceleration of ice loss and glacial erosion, Glaciar Marinelli, Chilean Tierra del Fuego. J. Glaciol 55, 207-220.

Koppes, M., et al., 2015a. Observed latitudinal variations in erosion as a function of glacier dynamics. Nature 526, 100-103.

Koppes, M., Rupper, S., Asay, M., Winter-Billington, A., 2015b. Sensitivity of glacier runoff projections to baseline climate data in the Indus River basin. Front. Earth Sci. 3.

Krater, J., Rose, M., 2009. Development of Iceland's geothermal energy potential for aluminium production-a critical analysis. Management 11, 9-19.

Kristiansen, S.M., et al., 2013. Geochemistry of groundwater in front of a warm-based glacier in Southeast Greenland: geochemistry of groundwater in front of a warmbased glacier in Southeast Greenland. Geogr. Ann. Ser. A Phys. Geogr 95, 97-108.

Kwong, H.T., Jiao, J.J., 2016. Hydrochemical reactions and origin of offshore relatively fresh pore water from core samples in Hong Kong. J. Hydrol. 537, 283-296.

Kwong, H.T., Jiao, J.J., Chan, L.S., 2016. A preliminary study on the offshore stratigraphy in Hong Kong and its hydrogeological implications. Environ. Earth Sci 75.

Labak-Mechowska, E., 2016. A description of the physical properties of selected sedi ments of the Weichselian and Wartanian glaciations. Bull. Geogr. Phys. Geogr. Ser 10.

Langston, G., Hayashi, M., Roy, J.W., 2013. Quantifying groundwater-surface water interactions in a proglacial moraine using heat and solute tracers: GW-SW Interaction in Proglacial Moraine. Water Resour. Res. 49, 5411-5426.

Lawler, D.M., Bjornsson, H., Dolan, M., 1996. Impact of subglacial geothermal activity on meltwater quality in the Jökulsá á Sólheimasandi system, southern Iceland. Hydrol. Process. 10, 557-578.

Legchenko, A., et al., 2014. Monitoring water accumulation in a glacier using magnetic resonance imaging. Cryosphere 8, 155-166.

Lemieux, J.-M., Sudicky, E.A., Peltier, W.R., Tarasov, L., 2008. Simulating the impact of glaciations on continental groundwater flow systems: 1. Relevant processes and model formulation. J. Geophys. Res. 113.

Levy, A., Robinson, Z., Krause, S., Waller, R., 2012. The impact of glacial fluctuations on the shallow proglacial groundwater systems of two SE Icelandic glaciers. In: EGU General Assembly Conference Abstracts. 14. pp. 898.

Levy, A., Robinson, Z., Krause, S., Waller, R., Weatherill, J., 2015. Long-term variability of proglacial groundwater-fed hydrological systems in an area of glacier retreat, Skeiðarársandur, Iceland: IMPACTS OF GLACIAL RETREAT ON PROGLACIAL GROUNDWATER-FED SYSTEMS. Earth Surf. Process. Landf. 40, 981-994.

Liu, J., et al., 2016. Assessment of different modelling studies on the spatial hydrological processes in an arid alpine catchment. Water Resour. Manag. 30, 1757-1770.

Lliboutry, L., 1968a. General theory of subglacial cavitation and sliding of temperate glaciers. J. Glaciol. 7, 21-58.

Lliboutry, L., 1968b. Théorie complète du glissement des glaciers, compte tenu du fluage transitoire. Assemblée Générale de Berne, Commission de Neiges et Glaces-Assoc, Intern. Hydrol. Sci. Publ 79, 33-48.

Lutz, A.F., Immerzeel, W.W., Shrestha, A.B., Bierkens, M.F.P., 2014. Consistent increase in High Asia's runoff due to increasing glacier melt and precipitation. Nat. Clim. Chang. 4, 587-592.

Malard, A., Sinreich, M., Jeannin, P.-Y., 2016. A novel approach for estimating karst groundwater recharge in mountainous regions and its application in Switzerland. Hydrol. Process. 30 (13), 2153-2166.

Marciniak, M., Dragon, K., Chudziak, L., 2014. Water circulation within a hig-Arctic glaciated valley (Petunia Bay, Central Spitsbergen): recharge of a glacial river. J. Hydrol. 513, 91-100.

Maréchal, J.-C., 2000. Massif du Mont-Blanc: identification d'une structure hydrogéeologique majeure. La Houille Blanche 6, 78-86.

Mark, B.G., Seltzer, G.O., 2005. Evaluation of recent glacier recession in the Cordillera Blanca, Peru (AD 1962-1999): spatial distribution of mass loss and climatic forcing Quat. Sci. Rev. 24, 2265-2280.

Mark, B.G., Bury, J., McKenzie, J.M., French, A., Baraer, M., 2010. Climate change and tropical Andean glacier recession: evaluating hydrologic changes and livelihood vulnerability in the Cordillera Blanca, Peru. Ann. Assoc. Am. Geogr. 100, 794-805.

Marteinsson, V.T., et al., 2013. Microbial communities in the subglacial waters of the Vatnajökull ice cap, Iceland. ISME J 7, 427-437.

McDowell, G., Koppes, M., 2017. Robust adaptation research in high mountains: integrating the scientific, social, and ecological dimensions of glacio-hydrological change. Water 9, 739 .

McIntosh, J.C., Walter, L.M., 2005. Volumetrically significant recharge of Pleistocene glacial meltwaters into epicratonic basins: constraints imposed by solute mass balances. Chem. Geol. 222, 292-309.

Meng, Y., Liu, G., Li, M., 2015. Tracing the sources and processes of groundwater in an alpine glacierized region in Southwest China: evidence from environmental isotopes. Water 7, 2673-2690.

Mikucki, J.A., et al., 2015. Deep groundwater and potential subsurface habitats beneath an Antarctic dry valley. Nat. Commun. 6 (6831).

Mir, R.A., Jeelani, G., Dar, F.A., 2016. Spatio-temporal patterns and factors controlling the hydrogeochemistry of the river Jhelum basin, Kashmir Himalaya. Environ. Monit. Assess. 188.

Montanaro, C., et al., 2016. Multidisciplinary constraints of hydrothermal explosions based on the 2013 Gengissig lake events, Kverkfjöll volcano, Iceland. Earth Planet. Sci. Lett. 434, 308-319.

Mukherji, A., Molden, D., Nepal, S., Rasul, G., Wagnon, P., 2015. Himalayan waters at the crossroads: issues and challenges. Int. J. Water Resour. Dev 31, 151-160.

Mukherji, A., Pradhan, N., et al., 2016. Community Training Manual - Springshed Management in the Hindu Kush Himalayas - Aspects of Groundwater and Hydrogeology.

Munoz Martinez, T., 2016. Contributions of Glacier Melting to the Upper Watershed of the Pita River, Ecuador.

Neupane, R.P., White, J.D., Allen, P.M., Dworkin, S.I., 2016. Sub-surface water contribution to recession flow in a mountain headwater stream system based on single monitoring campaign: sub-surface water contribution in a mountain stream. Hydrol. Process. 30, 899-913.

Nie, W., Krautblatter, M., Leith, K., Thuro, K., Festl, J., 2017. A modified tank model including snowmelt and infiltration time lags for deep-seated landslides in alpine environments (Aggenalm, Germany). Nat. Hazards Earth Syst. Sci. 17, 1595-1610.

Norphel, C., 2009. Artificial glaciers: a high altitude cold desert water conservation technique. In: Energy and Climate Change in Cold Regions of Asia, pp. 62-64.

Nüsser, M., Schmidt, S., 2017. Nanga Parbat revisited: evolution and dynamics of sociohydrological interactions in the Northwestern Himalaya. Ann. Am. Assoc. Geogr 107, 403-415.

Pärn, J., et al., 2016. The recharge of glacial meltwater and its influence on the geochemical evolution of groundwater in the Ordovician-Cambrian aquifer system, northern part of the Baltic Artesian Basin. Appl. Geochem. 72, 125-135.

Parriaux, A., Nicoud, G., 1993. De la montagne à la mer, les formations glaciaires et l'eau souterraine. Exemple du contexte Nord-alpin occidental. Quaternaire 4, 61-67.

Person, M., McIntosh, J., Bense, V., Remenda, V.H., 2007. Pleistocene hydrology of North America: The role of ice sheets in reorganizing groundwater flow systems: PLEISTOCENE HYDROGEOLOGY OF NORTH AMERICA. Rev. Geophys 45, n/a.

Piotrowski, J.A., 1997a. Subglacial groundwater flow during the last glaciation in northwestern Germany. Sediment. Geol. 111, 217-224.

Piotrowski, J.A., 1997b. Subglacial hydrology in north-western Germany during the last glaciation: groundwater flow, tunnel valleys and hydrological cycles. Quat. Sci. Rev. 16, 169-185.

Auvergne-Rhône-Alpes region Mountain Plan, 2016. Plan Montagne région AuvergneRhône-Alpes - acte I.

Pohl, E., Gloaguen, R., Andermann, C., Knoche, M., 2017. Glacier melt buffers river runoff in the Pamir Mountains: MELTWATER VARIABILITY IN THE PAMIR. Water Resour. Res. 53, 2467-2489.

Ponce-Vega, L.A., 2015. Puquios, qanats y manantiales: gestión del agua en el Perú antiguo. Agricultura, sociedad y desarrollo 12, 279-296.

Post, V.E.A., et al., 2013. Offshore fresh groundwater reserves as a global phenomenon. Nature 504, 71-78.

Poudel, D.D., Duex, T.W., 2017. Vanishing springs in Nepalese Mountains: assessment of water sources, farmers' perceptions, and climate change adaptation. Mt. Res. Dev. 37 $35-46$.

Qiu, Jane, 2016. Killer landslides: the lasting legacy of Nepal's quake. Nature 532, $428-431$.

Rabatel, A., et al., 2013. Current state of glaciers in the tropical Andes: a multi-century perspective on glacier evolution and climate change. Cryosphere 7, 81-102.

Radić, V., Hock, R., 2010. Regional and global volumes of glaciers derived from statistical upscaling of glacier inventory data. J. Geophys. Res. 115.

Ragettli, S., Pellicciotti, F., Immerzeel, W., 2015. Contrasting Response of Glacierized Catchments in the Central Himalaya and the Central Andes to Climate Change.

Ravazzani, G., Barbero, S., Salandin, A., Senatore, A., Mancini, M., 2015. An integrated hydrological model for assessing climate change impacts on water resources of the Upper Po River basin. Water Resour. Manag. 29, 1193-1215.

Reynard, E., 1995. L'irrigation par les bisses en Valais. Approche géographique. Annales valaisannes 70, 47-64.

Robinson, Z.P., Fairchild, I.J., Russell, A.J., 2008. Hydrogeological implications of glacial landscape evolution at Skeiðarársandur, SE Iceland. Geomorphology 97, 218-236.

Robinson, C. T., Tonolla, D., Imhof, B., Vukelic, R., Uehlinger, U., 2016. Flow intermittency, physico-chemistry and function of headwater streams in an Alpine glacial catchment. Aquat. Sci. 78, 327-341.

Roth, Pavoni, Deichmann, 1992. Seismotectonics of the eastern Swiss Alps and evidence for precipitation-induced variations of seismic activity. Tectonophysics 207 183-197.

Röthlisberger, H., 1972. Water pressure in intra- and subglacial channels. J. Glaciol. 11, 177-203.

Saar, M.O., Manga, M., 2003. Seismicity induced by seasonal groundwater recharge at Mt. Hood, Oregon. Earth Planet. Sci. Lett. 214, 605-618.

Saby, M., et al., 2016. Linking groundwater quality to residence times and regional geology in the St. Lawrence Lowlands, southern Quebec, Canada. Appl. Geochem. 65, $1-13$.

Salamon, T., 2016. Subglacial conditions and Scandinavian Ice Sheet dynamics at the coarse-grained substratum of the fore-mountain area of southern Poland. Quat. Sci. Rev. 151, 72-87.

Sauriol, J., 2016. Provenance of buried esker groundwater: the case of Vars-Winchester esker aquifer, Eastern Ontario, Canada. Hydrogeol. J. 24, 123-139.

Savéan, M., et al., 2015. Water budget on the Dudh Koshi River (Nepal): uncertainties on precipitation. J. Hydrol. 531, 850-862.

Schaefli, B., Manso, P., Fischer, M., Huss, M., 2016. The role of glaciers for Swiss hydropower production. In: EGU General Assembly Conference Abstracts. 18. pp. 1622. 
Schmidt, S., Nüsser, M., 2017. Changes of High Altitude Glaciers in the Trans-Himalaya of Ladakh over the past five decades (1969-2016). Geosciences 7, 27.

Schroeder, D.M., Blankenship, D.D., Young, D.A., 2013. Evidence for a water system transition beneath Thwaites Glacier, West Antarctica. Proc. Natl. Acad. Sci. 110, $12225-12228$.

Schwalbe, E., Koschitzki, R., 2016. Photogrammetric recognition of subglacial drainage channels during glacier lake outburst events. In: EGU General Assembly Conference Abstracts. 18. pp. 12254.

Sesiano, J., 1994. Etude limnogéologique et hydrogéologique des bassins-versants de Barberine et du Vieux-Emosson, Valais (Suisse). Arch. Sci. 47, 127-136.

Sesiano, J., 2004. L'hydrogéologie: 10 ans de recherches dans la région d'Emosson et du Fer-à-Cheval. Nature et Patrimoine en Pays de Savoie 11-21.

Siegert, M.J., Ross, N., Le Brocq, A.M., 2016. Recent advances in understanding Antarctic subglacial lakes and hydrology. Philos. Trans. R. Soc. A Math. Phys. Eng. Sci. 374, 20140306.

Sigurdsson, F., 1990. Groundwater from glacial areas in Iceland. Jökull 40, 119-146.

Sikorska, A.E., Viviroli, D., Seibert, J., 2015. Flood-type classification in mountainous catchments using crisp and fuzzy decision trees: FLOOD-TYPE CLASSIFICATION. Water Resour. Res. 51, 7959-7976.

Somers, L.D., et al., 2016. Quantifying groundwater-surface water interactions in a proglacial valley, Cordillera Blanca, Peru: groundwater tracing in a proglacial catchment. Hydrol. Process. 30, 2915-2929.

Stahl, K., Moore, R.D., Shea, J.M., Hutchinson, D., Cannon, A.J., 2008. Coupled modelling of glacier and streamflow response to future climate scenarios: MODELLING OF GLACIER AND STREAMFLOW. Water Resour. Res. 44.

Sterckx, A., Lemieux, J.-M., Vaikmäe, R., 2017. Representing glaciations and subglacial processes in hydrogeological models: a numerical investigation. Geofluids 2017, $1-12$.

Storrar, R.D., Evans, D.J.A., Stokes, C.R., Ewertowski, M., 2015. Controls on the location, morphology and evolution of complex esker systems at decadal timescales, Breiðamerkurjökull, southeast Iceland: controls on complex esker systems at Breiðamerkurjökull, Iceland. Earth Surf. Process. Landf. 40, 1421-1438.

Sudan, F.K., McKay, J., 2015. Climate adaptation and governance and small-scale farmers' vulnerability through artificial glacier technology: Experiences from the cold desert of Leh in North-West Himalaya, India. In: Shrestha, S., Anal, A.K., Salam, P.A., van der Valk, M. (Eds.), Managing Water Resources under Climate Uncertainty. Springer International Publishing, pp. 319-342.

Sveinsson, O., Linnet, U., Eliasson, E., 2010. Hydropower in Iceland Impacts and Adaption in Future Climate.

Tinoco, V., Kondolf, G.M., 2017. The New Wave of Hydroelectric Dams in the Andes: How Sustainable?.

(UNEP, 2007).

Vallet, A., Varron, D., Bertrand, C., Fabbri, O., Mudry, J., 2016. A multi-dimensional statistical rainfall threshold for deep landslides based on groundwater recharge and support vector machines. Nat. Hazards. https://doi.org/10.1007/s11069-0162453-3.

Van Vliet-Lanoë, B., 2014. Les environnements froids - glaciaire et périglaciaire. Vuibert.

Vergara, W., et al., 2007. Economic impacts of rapid glacier retreat in the Andes. Eos
Trans. AGU 88, 261-264.

Villacis, M., 2008. Ressources en eau glaciaire dans les Andes d'Equateur en relation avec les variations du climat: le cas du volcan Antisana. Ecole Polytechnique.

Vincent, A., Violette, S., 2017. Why seawater intrusion has not yet occurred in the Kaluvelli-Pondicherry basin, Tamil Nadu, India. Hydrogeol. J. https://doi.org/10. 1007/s10040-017-1558-4.

Vincent, A., Hart, J., Berry, C., 2017. Under the Glacier, the Groundwater - The Case of Skalafell Area, Iceland.

Vittecoq, B., et al., 2015. Heterogeneity of hydrodynamic properties and groundwater circulation of a coastal andesitic volcanic aquifer controlled by tectonic induced faults and rock fracturing - Martinique island (Lesser Antilles - FWI). J. Hydrol. https://doi.org/10.1016/j.hydrol.2015.09.022.

Vivian, R.A., Zumstein, J., 1973. Hydrologie sous-glaciaire au glacier d'Argentière (MontBlanc, France). IASH Publ 95, 53-64.

Vuille, M., 2013. Climate Change and Water Resources in the Tropical Andes. Inter American Development Bank.

Vuille, M., et al., 2018. Rapid decline of snow and ice in the tropical Andes - impacts, uncertainties and challenges ahead. Earth Sci. Rev. 176, 195-213.

Wadham, J.L., Cooper, R.J., Tranter, M., Bottrell, S., 2007. Evidence for widespread anoxia in the proglacial zone of an Arctic glacier. Chem. Geol. 243, 1-15.

Walder, J.S., Fowler, A., 1994. Channelized subglacial drainage over a deformable bed. J. Glaciol. 40, 3-15.

Wartman, J., et al., 2016. The 22 March 2014 Oso landslide, Washington, USA. Geomorphology 253, 275-288.

Werder, M.A., Funk, M., 2009. Dye tracing a jökulhlaup: II. Testing a jökulhlaup model against flow speeds inferred from measurements. J. Glaciol. 55, 899-908.

Werder, M.A., Loye, A., Funk, M., 2009. Dye tracing a jökulhlaup: I. Subglacial water transit speed and water-storage mechanism. J. Glaciol. 55, 889-898.

Werder, M.A., Schuler, T.V., Funk, M., 2010. Short term variations of tracer transit speed on alpine glaciers. Cryosphere 4, 381-396.

Wilson, A.M., Williams, M.W., Kayastha, R.B., Racoviteanu, A., 2016. Use of a hydrologic mixing model to examine the roles of meltwater, precipitation and groundwater in the Langtang River basin, Nepal. Ann. Glaciol. 57, 155-168.

Windsor, F.M., Grocott, M.T., Milner, A.M., 2017. An inter-catchment assessment of macroinvertebrate communities across groundwater-fed streams within Denali National Park, interior Alaska. Hydrobiologia 785, 373-384.

Wolf, Rowe, Horner, 1997. Periodic seismicity near Mt. Ogden on the Alaska-British Columbia border: A case for hydrologically triggered earthquakes? Bull. Seismol. Soc. Am 87, 1473-1483.

Xiang, L., et al., 2016. Groundwater storage changes in the Tibetan Plateau and adjacent areas revealed from GRACE satellite gravity data. Earth Planet. Sci. Lett. 449, 228-239.

Zeng, C., Liu, Z., Yang, J., Yang, R., 2015. A groundwater conceptual model and karstrelated carbon sink for a glacierized alpine karst aquifer, Southwestern China. J. Hydrol. 529, 120-133.

Zhang, X., Liu, S., Liu, L., 2015. Moraine-dammed glacial lake changes during the recent 40 years in the Poiqu River Basin, Himalayas. Sci. Cold Arid Regions 7, 0654-0665. 